Discussion Paper No. 04-54

\title{
Education, Gender and Earnings in France and Germany: Level and Dispersion Effects
}

Charlotte Lauer

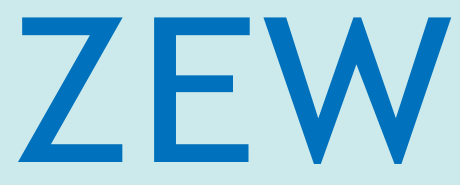

Zentrum für Europäische Wirtschaftsforschung $\mathrm{GmbH}$

Centre for European

Economic Research 
Discussion Paper No. 04-54

\title{
Education, Gender and Earnings in France and Germany: Level and Dispersion Effects
}

\author{
Charlotte Lauer
}

Download this ZEW Discussion Paper from our ftp server:

\begin{abstract}
ftp://ftp.zew.de/pub/zew-docs/dp/dp0454.pdf
\end{abstract}
Die Discussion Papers dienen einer möglichst schnellen Verbreitung von neueren Forschungsarbeiten des ZEW. Die Beiträge liegen in alleiniger Verantwortung der Autoren und stellen nicht notwendigerweise die Meinung des ZEW dar.

Discussion Papers are intended to make results of ZEW research promptly available to other economists in order to encourage discussion and suggestions for revisions. The authors are solely responsible for the contents which do not necessarily represent the opinion of the ZEW. 


\section{Non technical summary}

This paper analyses the relationship between education and earnings for men and women in France and Germany. It first adds to the existing literature through the comparison of France and Germany. The observation of the patterns prevailing both within and across countries enabled to gain new insights on the relationship between education and individual labour market success. A further contribution of this paper is a methodological innovation that makes it possible to assess the impact of educational attainment not only on the expected level of earnings but also on the earnings risk, measured here by the unexplained earnings variance. Moreover, the impact of education on the selective and gender-specific access to employment has been considered too.

The results indicate that the completion of a minimum level of general instruction yields an earnings premium that cannot be compensated by the completion a vocational degree. Moreover, basic vocational education leads to a higher earnings premium in Germany than in France. This points to the better efficiency of the German system of vocational education compared to the low-status vocational education in France, which remains rather theoretical, less connected to the job market, and signals failure in general education. The completion of higher education yields a particularly high earnings premium in both countries, but particularly in France, though study duration is typically shorter. This is most probably the effect of the presence of elite institutions in France. Furthermore, in both countries but especially in Germany, women have a lower educational attainment than men but enjoy a higher earnings premium for education, anything else equal. The gender gap in the earnings premium for education is much larger in Germany than in France.

Moreover, education affects the uncertainty of earnings. In both countries, general qualifications are found to increase the earnings risk, whereas vocational one to reduce it. More education, especially tertiary education, yields a high earnings premium but is associated with the highest earnings uncertainty in both counties. Looking at the effect of gender reveals further common patterns. Women have overall lower earnings and a higher earnings dispersion. However, they enjoy a higher earnings premium for education than men on average, and though they face overall a higher earnings uncertainty, they can to a larger extent than men reduce this risk by investing in their education.

The findings show that only examining the effect of education in terms of earnings level illustrates only one aspect of the relationship between education and earnings. The level of education attained is not neutral with respect to earnings dispersion, even after controlling for gender-specific selection into employment and a large number of explanatory factors. 


\title{
Education, gender and earnings in France and Germany: level and dispersion effects
}

\author{
Charlotte Lauer* \\ Centre for European Economic Research \\ Zentrum für Europäische Wirtschaftsforschung (ZEW) \\ Mannheim
}

\begin{abstract}
This paper analyses the relationship between education, gender and earnings in France and Germany. The model chosen here enables to estimate the impact of education not only on the expected earnings level but also on their dispersion, taking gender-specific sample selectivity into account. The results indicate that the completion of a minimum level of general instruction yields an earnings premium that cannot compensated by a vocational degree. Moreover, education affects the uncertainty of earnings. General qualifications are found to increase the earnings risk, vocational one to reduce it. More education, especially tertiary education, yields a high earnings premium but is associated with the highest earnings uncertainty. Women enjoy a higher earnings premium for education than men and though they face overall a higher earnings uncertainty, they can - more than men - reduce this risk by investing in their education.
\end{abstract}

JEL classification: I2; J3

Keywords: education, earnings, heteroscedasticity

* The author is associate researcher at the Equipe de Recherche sur les Marchés, l'Emploi et la Simulation (ERMES), University of Panthéon-Assas, Paris II.

\section{Acknowledgement:}

Financial support from the European Commission under the project

"Education and Wage Inequality" (EDWIN) is gratefully acknowledged. 


\section{Introduction}

France and Germany have chosen rather different options for their education systems, in particular concerning the degree to which labour market aspects are taken into consideration. As an example, the German system of vocational education, with the apprenticeship, is more closely linked to needs of the labour market than the French one, in which general education has a higher priority. Conversely, at the higher education level, the French system is more oriented towards practice than the German one, with the presence of the Grandes Ecoles and a variety of practically oriented short tracks. In previous work (Lauer, 2003a), it was found that this different prioritization at different levels of the education system had implications in terms of unemployment risk, proved more or less efficient in terms of access to and securing of employment. In this paper, I examine whether similar effects are observable when considering not only access to employment but also the quality of the employment acceeded, taking labour earnings as an indicator. The patterns observed within and between countries are expected to provide information on the efficiency of the respective education systems as providers of qualifications to be used on the labour market.

The link between education and earnings has been the object of numerous empirical studies in the past few decades, following the development of the human capital theory pioneered by Becker (1964) and Mincer (1974) and the spread of data sets available for research. Nevertheless, separate studies for either France or Germany are hardly comparable due to different methodologies or fields of observation and a look at the empirical evidence available so far reveals that there is no really comparative research on this subject for France and Germany. Among the exceptions, Kaukewitsch and Rouault (1998) realised a comparison of wage hierarchies in France and West Germany for 1995. However, the analysis is based on occupation levels rather than education levels. Another comparison of France and Germany is that of Brauns, Müller and Steinmann (1997), but in that case, the analysis does not deal with earnings but with social class position. Besides, even though the literature on education and level of earnings is large (see for instance the overview of the literature in Europe by Asplund and Pereira (1999), there is much less empirical evidence on the impact of education on earnings dispersion. The only study covering both France and Germany in that respect is that by Pereira and Martins (2000), who ran parallel quantile regressions of very parsimonious earnings equations for a wide range of European countries. Because education is solely measured as years of schooling, the interpretation of the results is of limited interest for French and German education policy, though. This paper aims to fill in this gap in research.

To be more specific, the aim of this paper is to examine the earnings prospects that can be expected from the completion of various types and levels of qualification produced by the French and German education systems, not only in terms of level of earnings but also in terms of earnings dispersion. If education is viewed, following human capital theory, as an investment that yields on average a positive return, 
then, the riskiness of that investment should also be considered. In this study, the residual earnings dispersion, i.e. the variance in earnings that is not explained by the observables, will be considered as a measure of the remaining earnings uncertainty or briefly speaking, as a measure of earnings risk. Thus, in addition to the average earnings premium to be expected from the investment in education, the paper aims to determine its impact on the earnings risk. A specific modelling design has been developed for this purpose. Basically, the econometric model proposed here is an extension of the Mincerian earnings equation derived from the human capital theory (Mincer, 1974) to both account for sample selection and model the impact of education on earnings uncertainty. Hereby, a particular focus is laid on the examination of gender differences as well as on the distinction between general and vocational education.

The chapter is structured as follows. After presenting some stylised facts on the relationship between education and earnings (section 2), section 3 presents the modelling framework used for the econometric analysis. Then, the data used as well as the way the variables have been constructed are explained in section 4 . Finally, the results of the estimations are presented. The presence, the determinants and the impact of the selectivity on the estimated impact of education on earnings level and dispersion are described in section 5, whereas the estimated impact of educational attainment in terms of average earnings premium and residual earnings dispersion are presented in section 6 . Finally, section 7 summarises the key findings and draws some conclusions.

\section{Education and earnings: descriptive evidence}

Let us first examine the distribution of earnings in both countries. Figure 1 depicts the mean (primary axis) and the variance (secondary axis) of log hourly earnings in France and Germany in $2000^{1}$, overall as well as separately for men and women, based on data from the Emploi survey for France and from the GSOEP for Germany. The German sample is restricted to West German residents and for both countries, the analyses focus on nationals or individuals born in the country and aged between 25 and 55. Moreover, I focus on regular employment and therefore exclude the minimally employed (below 15 work hours a week) as well as those individuals who report working more than 60 hours a week as a regular working time since the latter does not seem not very plausible.

1 For both countries, the gross hourly earnings measure is computed from the gross monthly earnings perceived in the month preceding the interview, expressed in Euros, divided by the number of hours worked in that month. In the Emploi survey, gross monthly earnings are given without the social security contributions paid by the employee, unlike in the GSOEP data. In order to make figures comparable, the French earnings data were augmented by 20 percent, which corresponds to the level of social security contributions (see Kaukewitsch and Rouault, 1998).Irregular payments from the previous year like a 13th month pay or a bonus have been added to the gross earnings proportionally. Following Mincer (1974), the logarithm of this measure of earnings is taken as outcome of interest for the subsequent econometric study. 
Figure 1: Gross hourly earnings by gender (2000)

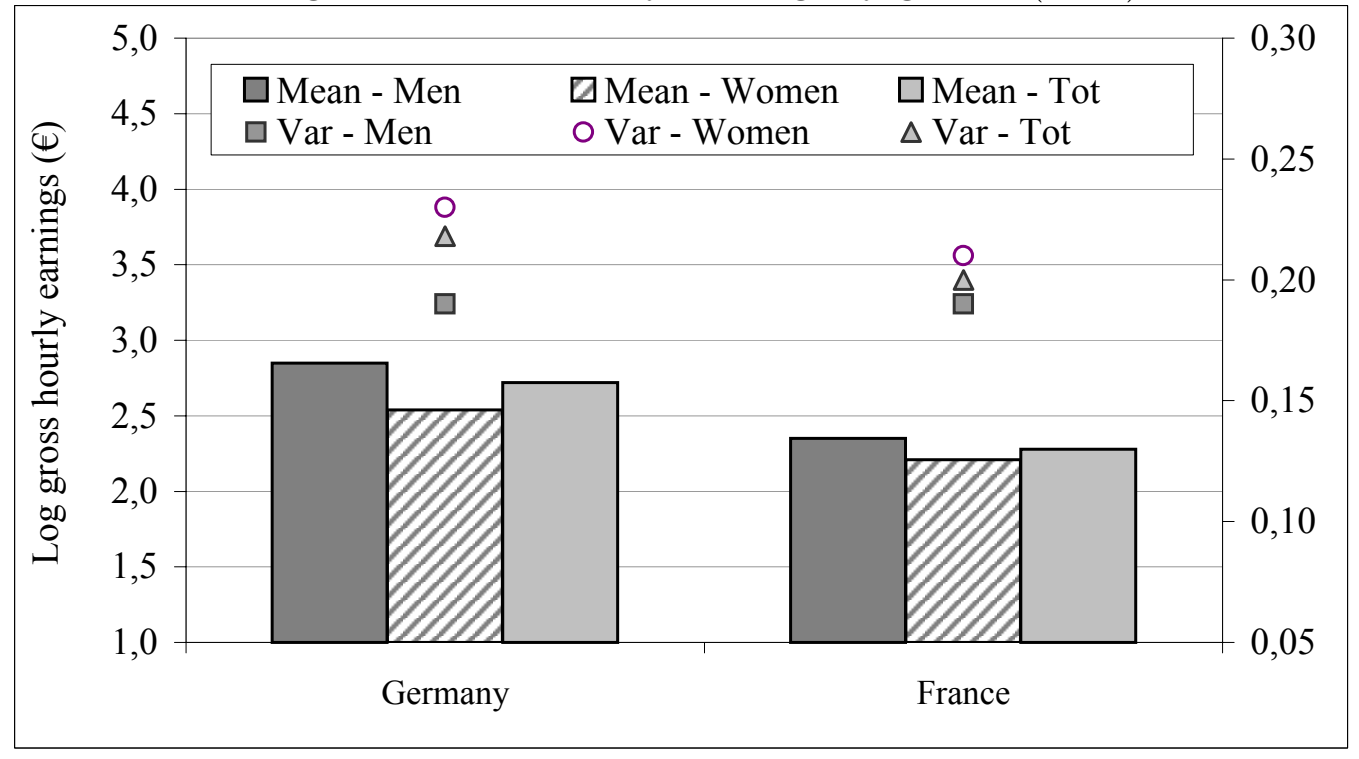

As appears from figure 1, the average earnings are higher in Germany than in France. Men perceive higher earnings than women in both countries, but the gender gap is significantly larger in Germany than in France. Moreover, the overall variance of earnings is higher in Germany than in France. The earnings variance proves higher for women than for men in both countries, but particularly in Germany. As a result, the earnings variance is rather similar for French and German men (it is even slightly higher for French men), but it is much higher for German women than for French women.

Let us now have a look at the distribution of earnings by education level. The level of educational attainment is defined by a combination of the highest degrees obtained in general and in vocational education according to the typology reported in table 1. Figure 2 shows that the average earnings are higher in Germany than in France at all education levels. The only exception are individuals with level 10 education, i.e. without any degree, for which the earnings are slightly higher in France, though minimally ${ }^{2}$. This might be an effect of the French minimum wage. In both countries, individuals with no degree at all (level 10) have the lowest earnings, individuals with a tertiary level degree the highest earnings. Between these extremes, however, the progression of average earnings is not monotonous. The discriminating power of education is stronger in Germany than in France.

Another feature that emerges from figure 2 is that the variance of earnings is higher at low qualification levels but also at university levels, while it is lowest for basic and advanced vocational qualifications. This is true in both countries. Interestingly, general maturity graduates who do not possess any vocational qualification show to have a particularly high earnings dispersion in both countries. Thus, it

2 Note, however, that this category comprises almost 18 percent of the population in France in 2000, against less than 1 percent in Germany. 
Table 1: Typology of educational attainment

Highest degree obtained

\section{Level 1 No vocational qualification}

$10 \quad$ No degree

11 Lower secondary education

12 Intermediate secondary education

\section{Level 2 Basic vocational qualification}

20 No or lower secondary education + basic vocational degree

21 Intermediate secondary education + basic vocational degree

\section{Level 3 Intermediate qualification}

30 Intermediate vocational degree

$31 \quad$ Vocational maturity certificate

32 General maturity certificate

33 General maturity certificate + vocational degree

\section{Level 4 Tertiary level qualification}

$40 \quad$ Lower tertiary education

41 Upper tertiary education

Source: Lauer (2001)

Figure 2: Gross hourly earnings by detailed education level (2000)

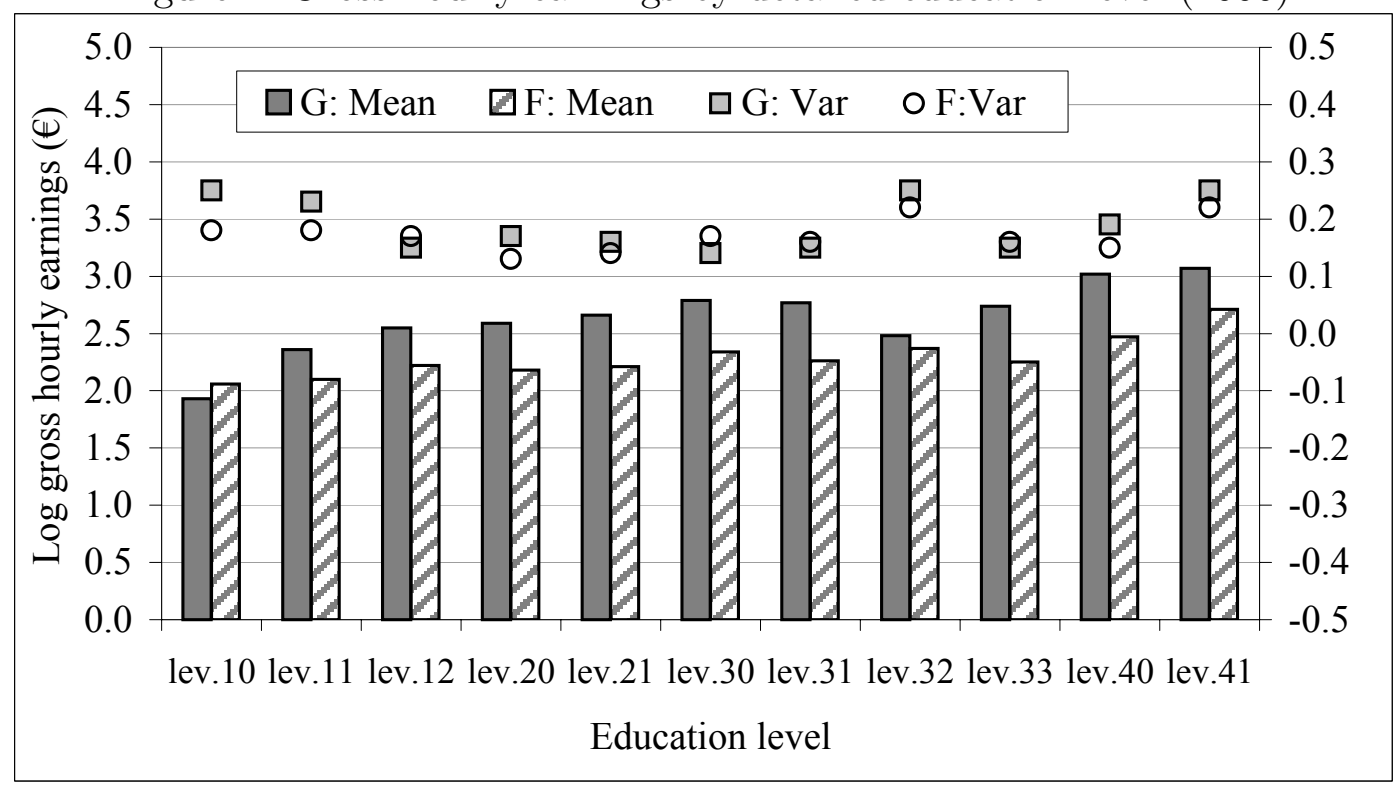

seems that vocational qualifications, as opposed to general qualifications, are associated with a lower variance of earnings.

Overall, the descriptive analysis provided first evidence that not only the level of earnings varies across education levels and types but also their variance. This will be further analysed in the subsequent econometric analysis. 


\section{Modelling framework}

Most empirical studies that examine the link between education and private earnings are imbedded in the human capital theory as pioneered by Becker (1964) and Mincer (1974). The basic idea of the human capital theory is that the acquisition of education, or more generally of human capital, can be viewed as an investment in the sense that a current earnings sacrifice or cost is incurred in order for a future benefit. The costs consist primarily of the foregone earnings arising from the time diverted from the labour market to acquire the incremental human capital unit, but there might also be direct costs. The benefits arise through the extra earnings obtained from additional education during the working life. The latter aspect is the object of this study. To be more specific, the aim is here to investigate for France and Germany how educational attainment is rewarded in terms of earnings, abstracting from the other factors that might affect earnings and education. Doing so, one can estimate what I call here the earnings premium for education, i.e. the effect of attaining a specific education level on the earnings prospects, anything else being equal.

Particular efforts have been put in not only modelling the average effect of education on earnings, but also its impact in terms of earnings dispersion. The latter aspect has been relatively little investigated in the literature until now. Besides, it is known that there are substantial differences between France and Germany in the access to employment, regarding both labour force participation and the incidence of unemployment (see for instance Lauer and Weber, 2003 and Lauer, 2003a). Therefore, neglecting the effect of selectivity into employment, which conditions whether we observe labour earnings, could bias the estimated earnings premium for education or its effect on earnings dispersion. This is why the selectivity into employment will be explicitly modelled here.

\subsection{A sample selection model with multiple heteroscedas- ticity}

The first step of the model development consists in using a standard extension of Mincer (1974)'s so as to take selectivity into employment into account. Let the model be defined as follows:

$$
\begin{aligned}
& \ln y_{1 i}=x_{i} \beta+\varepsilon_{1 i} \quad \text { if } \quad y_{2 i}^{*}>0 \\
& \ln y_{1 i}=\text { not observed if } y_{2 i}^{*} \leq 0 \\
& y_{2 i}^{*}=z_{i} \gamma+\varepsilon_{2 i} \\
& y_{2 i}=1 \text { if } y_{2 i}^{*}>0 \\
& y_{2 i}=0 \text { if } \quad y_{2 i}^{*} \leq 0
\end{aligned}
$$

$y_{1 i}$ is the variable indicating the earnings perceived by individual $i, i \in\{1 \ldots N\}$. $y_{1 i}$ is assumed to be a linear function of some human capital variables contained in 
the vector $x_{i}$ and some unobserved component $\varepsilon_{1 i}$. $\beta$ is the vector of coefficients - to be estimated - that describe the way the explanatory variables affect the expected earnings. The earnings can only be observed for people who actually perceive earnings, which is indicated by the binary variable $y_{2 i}$, which takes the value 1 if the earnings of individual $i$ are observed and 0 otherwise. $y_{2 i}^{*}$ is the corresponding latent - continuous - variable which describes the propensity to be selected in the sample of observations for which earnings are observed. The selection propensity depends in a linear way on some variables contained in the vector $z_{i}$, the effect of which being captured by the coefficient vector $\gamma$, and on some unobserved factors $\varepsilon_{2 i}$. If the selection process and the determination of wages were independent from each other, one could estimate the equations separately without bias. However, the sample of individuals for whom we observe earnings might not be a random sample of the whole population. Therefore, instead of assuming the independence of the error terms of the selection and of the wage equation, I will assume, in the spirit of Heckman (1979), that they are jointly distributed with a bivariate normal distribution of the following form:

$$
\left(\begin{array}{c}
\varepsilon_{1 i} \\
\varepsilon_{2 i}
\end{array}\right) \sim \mathcal{N}\left(\left(\begin{array}{l}
0 \\
0
\end{array}\right),\left(\begin{array}{cc}
\sigma_{1 i}^{2} & \varrho \sigma_{1 i} \\
\varrho \sigma_{1 i} & \sigma_{2 i}^{2}
\end{array}\right)\right)
$$

where $\mathcal{N}$ denotes the bivariate normal distribution function. $\varrho$ measures the correlation between $\varepsilon_{1 i}$ and $\varepsilon_{2 i}$. This correlation will be allowed to differ across a limited number of population groups (e.g. here between men and women $\varrho=\varrho_{\text {men }}$ or $\varrho_{\text {women }}$ ). Two types of observations enter the likelihood function of the model described by equations (1) and (2): the observations for which no earnings are observed, and the observations for which the earnings are observed. The likelihood for the complete sample is then:

$$
\mathcal{L}=\prod_{i=1}^{n_{0}} 1-\Phi\left(z_{i} \gamma / \sigma_{2 i}\right) \prod_{i=n_{0}+1}^{N} \frac{1}{\sigma_{1 i}} \phi\left(\frac{y_{1 i}-x_{i} \beta}{\sigma_{1 i}}\right) \Phi\left(\frac{z_{i} \gamma+\left(\varrho / \sigma_{1 i}\right)\left(y_{1 i}-x_{i} \beta\right)}{\sqrt{\sigma_{2 i}^{2}-\varrho^{2}}}\right)
$$

where there are $n_{0}$ observations for which earnings are not observed and $N-n_{0}$ observations for which earnings are observed.

The sample selection model described above requires some further assumption onto the variances in order to be identifiable and estimable empirically. A widely used assumption in the empirical literature is the homoscedasticity of the disturbances, both for the selection and for the main equation. As a result, $\sigma_{1 i}$ simplifies to $\sigma_{1}$ and $\sigma_{2 i}$ to $\sigma_{2}$. Moreover, $\sigma_{2}$ is typically normalised to 1 , without loss of generality, because in the probit equation, $\gamma$ and $\sigma_{2}$ are not separately identified but only the ratio $\gamma / \sigma_{2}$ is identified. This homoscedasticity assumption makes the estimation far easier from a practical point of view but gives rise to some problems in the context of the present study. First, both estimation are estimated simultaneously by maximum likelihood. As soon as the model is non linear, the estimated coefficients 
themselves are biased in the presence of heteroscedasticity, not only the standard errors. Moreover, the model should allow the modelling of the effect of education on the residual dispersion, not only on levels. Therefore, the specification of the model will be adapted to allow the disturbances to be heteroscedastic, both in the selection nor in the earnings equation. Here, a multiplicative form of heteroscedasticity is used, which is known (e.g. Greene (2000), p.518) to be a very flexible and general model:

$$
\begin{aligned}
& \ln \sigma_{1 i}^{2}=x_{i}^{h} \beta^{h} \\
& \ln \sigma_{2 i}^{2}=z_{i}^{h} \gamma^{h}
\end{aligned}
$$

The vector $x_{i}^{h}$ includes a constant term $\beta_{0}^{h}$. Thus, if $x_{i}^{h}$ contains a set of dummy variables, one of which - the base group - having been left out, then, $\exp \left(\beta_{0}^{h}\right)$ provides an estimator of the disturbance variance for the base group and the other coefficients of $\beta^{h}$ indicate in which direction and how far the disturbance variance of the other categories deviates from that of the reference group. For $\sigma_{2 i}^{2}$ to be normalisable to 1 , failing which the model is not identified, $z_{i}^{h}$ should not entail a constant term. $\sigma_{1 i}^{2}$ and $\sigma_{1 i}^{2}$ can be replaced by the expressions (5) in the log likelihood function defined in equation (4).

\subsection{Computation of level and dispersion effects of education on earnings}

Let us concretise the model presented in the following way:

$$
\begin{aligned}
x_{i} & =\left[1, \text { educ, educ } \times \text { female }, \text { female }, \tilde{x}_{i}\right] \\
\beta & =\left[\beta_{0}, \beta_{1}, \beta_{2}, \beta_{3}, \tilde{\beta}\right]
\end{aligned}
$$

and

$$
\begin{aligned}
x_{i}^{h} & =\left[1, \text { educ, educ } \times \text { female, female }, \tilde{x}_{i}^{h}\right] \\
\beta^{h} & =\left[\beta_{0}^{h}, \beta_{1}^{h}, \beta_{2}^{h}, \beta_{3}^{h}, \tilde{\beta}^{h}\right]
\end{aligned}
$$

where female is a dummy variable that indicates whether the individual is a women, and $e d u c$ is a vector depicting educational attainment as a set of dummy variables the meaning of which can be read in table 1 :

$$
\begin{array}{r}
\text { educ }=[\text { level } 12, \text { level } 20, \text { level } 21, \text { level } 30, \text { level } 31, \\
\text { level } 32, \text { level } 33, \text { level } 40, \text { level } 41]
\end{array}
$$

$e d u c \times$ female is the vector of interactions between female and educ. $\tilde{x}_{i}$ and $\tilde{x}_{i}{ }^{h}$ are the vectors comprising all other explanatory variables, $\tilde{\beta}$ and $\tilde{\beta}^{h}$ the corresponding coefficients vectors. Thus, equations (1) can be rewritten as:

$$
\begin{aligned}
\ln y_{1 i}= & \beta_{0}+\beta_{1} \text { educ }+\beta_{2} \text { educ } \times \text { female }+\beta_{3} \text { female } \\
& +\tilde{x}_{i} \tilde{\beta}+\varepsilon_{1 i} \quad \text { if } \quad y_{2 i}^{*}>0 \\
\ln y_{1 i}= & \text { not observed } \quad \text { if } \quad y_{2 i}^{*} \leq 0
\end{aligned}
$$


and the scedastic equation (5) as:

$$
\ln \sigma_{1 i}^{2}=\beta_{0}^{h}+\beta_{1}^{h} e d u c+\beta_{2}^{h} e d u c \times \text { female }+\beta_{3}^{h} \text { female }+\tilde{x}_{i}^{h} \tilde{\beta}^{h}
$$

The coefficients of the education variables in equations (9) and (10) give a measure of the effects of education on the expected level of earnings (called average earnings premium her, or AEP, with a standard error $\mathrm{SE}(\mathrm{AEP})$ ) and on their unexplained dispersion (called earnings dispersion effect here or EDE, with a standard error $\mathrm{SE}(\mathrm{EDE}))$ respectively. The estimated effects of the attaining the education level considered are to be interpreted in reference to the group of individuals with poor (level 10 or 11) education.

The earnings premium obtained for a same education level on average might differ between men and women. For men, the effects can be read directly from the estimated coefficients and standard errors:

$$
\begin{aligned}
A E P_{m e n} & =\hat{\beta}_{1} \\
S E(A E P)_{m e n} & =\sqrt{\operatorname{var}\left(\hat{\beta}_{1}\right)} \\
E D E_{m e n} & =\hat{\beta_{1}^{h}} \\
S E(E D E)_{m e n} & =\sqrt{\operatorname{var}\left(\hat{\beta}_{1}^{h}\right)}
\end{aligned}
$$

For women, the effects of education on earnings cannot be read directly from the table of coefficients, but can be computed as:

$$
\begin{aligned}
A E P_{\text {women }} & =\hat{\beta}_{1}+\hat{\beta}_{2} \\
S E(A E P)_{\text {women }} & =\sqrt{\operatorname{var}\left(\hat{\beta}_{1}\right)+\operatorname{var}\left(\hat{\beta}_{1}\right)+2 \operatorname{cov}\left(\hat{\beta}_{1}, \hat{\beta}_{2}\right)} \\
E D E_{\text {women }} & =\hat{\beta_{1}^{h}}+\hat{\beta}_{2}^{h} \\
S E(E D E)_{\text {women }} & =\sqrt{\operatorname{var}\left(\hat{\beta}_{1}^{h}\right)+\operatorname{var}\left(\hat{\beta}_{1}^{h}\right)+2 \operatorname{cov}\left(\hat{\beta_{1}^{h}}, \hat{\beta}_{2}^{h}\right)}
\end{aligned}
$$

where $\overline{\text { female }}$ is the proportion of females in the sample.

The overall level and dispersion effects of education, regardless of gender, can therefore be computed as:

$$
\begin{aligned}
& A E P_{\text {all }}=\hat{\beta}_{1}+\overline{\text { female }} \hat{\beta}_{2} \\
& S E(A E P)_{\text {all }}=\sqrt{\operatorname{var}\left(\hat{\beta}_{1}\right)+\overline{\text { female }}^{2} \operatorname{var}\left(\hat{\beta}_{1}\right)+2 \overline{\text { female }} \operatorname{cov}\left(\hat{\beta}_{1}, \hat{\beta}_{2}\right)} \\
& E D E_{\text {all }}=\hat{\beta_{1}^{h}}+\overline{\text { female }} \hat{\beta_{2}^{h}} \\
& S E(E D E)_{\text {all }}=\sqrt{\operatorname{var}\left(\hat{\beta}_{1}^{h}\right)+\overline{\text { female }}^{2} \operatorname{var}\left(\hat{\beta}_{1}^{h}\right)+2 \overline{\text { female }} \operatorname{cov}\left(\hat{\beta}_{1}^{h}, \hat{\beta}_{2}^{h}\right)}
\end{aligned}
$$


Thus, the maximisation ${ }^{3}$ of the resulting log-likelihood function permits to get estimates of the effects of education on earnings both in terms of level and of dispersion, while differentiating both aspects according to selected observed characteristics such as gender and controlling for (gender-specific) selection into employment.

\section{Data and variables}

As mentioned at the beginning of section 2, the empirical analysis is based on a sample of individuals (nationals or born in the respective country) aged 25 to 55 drawn from the Emploi survey for France and from the GSOEP data for Germany. The econometric analysis uses the waves 1991 to 2000, since no continuous measure of earnings is available before this date in the French data set ${ }^{4}$. The dependent variable for the earnings equation (1) is the logarithm of the gross hourly earnings such as defined in section $2^{5}$. For the selection equation, the dependent variable is defined by a binary variable indicating whether the information on gross hourly earnings is available for the individual considered.

Table 2 provides a synthetic overview of the explanatory variables used for the econometric analysis, distinguishing between variables included in both the selection and the earnings equation, variables included only in the earnings equation and variables included only in the selection equation. Special attention has been paid to using the same variables for both countries and defining them in a way as similar as possible. Summary statistics for all the variables used are provided in appendix (table 5).

Education ${ }^{6}$ and gender, as well as interactions between them, are the key vari-

3 See in Gould and Sribney (1999) how to programme maximum likelihood estimations with the software package Stata.

4 Because both the GSOEP and the Emploi survey are longitudinal data sets, one might think of exploiting the repeated observations of same individuals over time to isolate individual effects. However, random effects estimates are inconsistent because the individual effects are correlated with the regressors and fixed effect or first differences estimators cannot be used because gender and education are basically time-invariant. If one assumes that the unobserved individual factors have a similar effect in both countries, however, the comparison of the results across countries should be little affected.

5 The earnings in the years preceding the introduction of the Euro have been converted in Ecus. The earnings have then been deflated on the basis of the consumer price index so that all earnings are expressed in prices of 2000.

6 The endogeneity of schooling in earnings equation and the correction of the bias caused by it has been the object of numerous studies (e.g. Card, 2000). However, the literature leads to controversial conclusions as to the optimal correction of the endogeneity problem, one important problem lying in the non-availability of valid instruments (see Lauer and Steiner, 2001; Card, 2000; Heckman, Lochner and Todd, 2003). Therefore, as in Harmon, Hogan and Walker (2003) education is considered exogenous, conditional on the other explanatory variables. This should be a minor problem here since the inclusion of father's occupation as additional explanatory factor is likely to reduce the endogeneity problem and the focus of the analysis is on comparing the hierarchy and the dispersion of the earnings premia for different education levels across countries rather than determining their absolute levels. 
ables included in the selection and earnings equations, both in the level component and in the scedastic equation to examine how the earnings level and unexplained variance depend on education and whether this effect depends on gender. Further key variables, age and a yearly trend, have been added in the scedastic function as

Table 2: Explanatory variables

\begin{tabular}{|c|c|}
\hline Variables & Definition \\
\hline \multicolumn{2}{|c|}{ Variables common to both the selection and the earnings equation } \\
\hline Education level & $\begin{array}{l}10 \text { categories: level } 10 / 11 \text {; level } 12 \text {; level } 20 \text {; level } 21 \text {; } \\
\text { level } 30 ; \text { level } 31 \text {; level } 32 \text {; level } 33 \text {; level } 40 \text {; level } 41 \\
\text { (see table } 1 \text { ) }\end{array}$ \\
\hline Sex & 2 categories: female; male \\
\hline Age & polynome: age; age squared \\
\hline Current quarter & $\begin{array}{l}\text { Germany: } 3 \text { categories: } 1 \text { st quarter (January to March); } \\
\text { 2nd quarter (April to June); 3rd/4th quarter (July to } \\
\text { December) } \\
\text { France: } 2 \text { categories: } 1 \text { st quarter (January to March); } \\
\text { 2nd/4th quarter (April to December) }\end{array}$ \\
\hline Time trend & 10 year dummies: 1991 to 2000 \\
\hline \multicolumn{2}{|c|}{ Variables specific to the earnings equation } \\
\hline Tenure & polynome: years of tenure; years of tenure squared \\
\hline Firm size & $\begin{array}{l}6 \text { categories: }<5 \text { employees; 5-19 employees; } 20-199 \\
\text { employees; 200-1999 employees; } \geq 2,000 \text { employees; } \\
\text { missing }\end{array}$ \\
\hline Industry & $\begin{array}{l}9 \text { categories: industry (mechanical and electrical engi- } \\
\text { neering, stone, iron, steel and chemical industry, paper, } \\
\text { textile, food industry, other); agriculture/energy (agri- } \\
\text { culture, forestry, fishing, energy, mining); construction; } \\
\text { trade (wholesale and retail); banking (banking, insurance, } \\
\text { real estate); transports (transports and communications); } \\
\text { private services (personal services, eating and drinking, } \\
\text { other services to professionals or private households); } \\
\text { public services (welfare services, government, non-profit } \\
\text { institutions, other); missing }\end{array}$ \\
\hline Fixed-term contract & 2 categories: not fixed term; fixed term \\
\hline Part-time employment & 2 categories: full-time; part-time \\
\hline Public employment & 2 categories: private employment; public employment \\
\hline Father's occupation & $\begin{array}{l}7 \text { categories: worker; farmer; self-employed; senior } \\
\text { manager; middle-level manager; employee; missing }\end{array}$ \\
\hline
\end{tabular}

to be continued... 


\begin{tabular}{|c|c|}
\hline Variables & Definition \\
\hline \multicolumn{2}{|c|}{ Variables specific to the selection equation } \\
\hline Marital status & 2 categories: married; not married \\
\hline $\begin{array}{l}\text { Number and age of } \\
\text { children below } 18\end{array}$ & $\begin{array}{l}10 \text { categories: no children; } 1 \text { child aged } 6-17 ; 1 \text { child aged } \\
3-5 ; 1 \text { child aged } 0-2 ; 2 \text { children, youngest aged } 6-17 \text {; } \\
2 \text { children, youngest aged } 3-5 ; 2 \text { children, youngest aged } \\
0-2 ; \text { more than } 2 \text { children, youngest aged } 6-17 ; \text { more } \\
\text { than } 2 \text { children, youngest aged } 3-5 \text {; more than } 2 \text { children, } \\
\text { youngest aged } 0-2\end{array}$ \\
\hline Partner's education & 4 categories: level 1 ; level 2 ; level 3 ; level 4 (see table 1$)$ \\
\hline Partner's earnings & gross monthly earnings (prices of 2000) \\
\hline $\begin{array}{l}\text { No info on partner's } \\
\text { earnings }\end{array}$ & 2 categories: information; no information \\
\hline No partner & 2 categories: partner; no partner \\
\hline Home ownership & $\begin{array}{l}2 \text { categories: owner of the house/appartment living in } \\
\text { (himself or spouse); not owner }\end{array}$ \\
\hline City size & $\begin{array}{l}3 \text { categories: fewer than } 20,000 \text { inhabitants; between } 20 \\
\text { and } 100,000 \text { inhabitants; } 100,000 \text { inhabitants or more }\end{array}$ \\
\hline
\end{tabular}

well to clean the estimates from these effects ${ }^{7}$. Further control variables have been included as reported in table 2 in the main equations for both earnings and the selection process in order to control for observed heterogeneity and isolate the labour market reward of education if everything else is equal.

Let us now turn to the estimation results. Both equations (2) and (1) have been estimated simultaneously as well as the correlation between them through the maximisation of the log-likelihood function (4), where both the level and the variance of earnings is allowed to differ by education and gender according to the function (5). The correlation is allowed to be different for men and women.

\section{$5 \quad$ Selectivity into paid employment}

This section presents the results concerning selectivity into paid employment. Table 6 in appendix reports overall statistics as well as the results of specification tests for the selection equation. Only the variables that are significant at the 10 percent level at least have been finally retained in the equation. It appears that the determinants of the employment propensity differ significantly across genders. The hypothesis of homoscedastic disturbances is also strongly rejected. Moreover, judging from the

7 In principle, one could include all explanatory variables of the main equation in the scedastic equation as well, but the number of variables should not be too high to leave enough variation in the scedastic terms. Several experiments with more variables in the scedastic equation showed that the estimates of the impact education are hardly affected, but the estimates become less robust if the number of variables is too high, especially for Germany. 
result of the corresponding test ${ }^{8}$, the exclusion restrictions seem reasonably valid (see Puhani, 2000).

Table 3 reports the full estimation results for the selection equation. In the upper part of the table, the mean effects are reported, i.e. the coefficients estimated for vector $\gamma$ (see equation (2)). The lower part of the table reports the dispersion effects, i.e. the coefficients estimated for the scedastic function (vector $\gamma^{h}$, see equation (5)). Since the focus of the study is on education and earnings, the comments concentrate on the impact of education, differentiated by gender, on the propensity of selection into paid employment and on the impact of selectivity on the estimated educationearnings link. The effect of the other variables can be read from table 3 and will not be further commented here.

The effect of educational attainment on the propensity to be engaged in paid employment differs between men and women. For men, the effect of education can be read directly from the coefficients of the education variables reported in table 3. In Germany, the probability of being employed for men with level 12 education (Realschule degree) does not differ significantly from that of the reference group, but from this level onwards, it rather increases with education. In France also, the work propensity of men rather tends to increase with education. Thus, poorly qualified men (level 10 and 11) have the lowest, tertiary level graduates the highest selection propensity. However, the coefficients are smaller in scope for French men compared to their German counterparts, which indicates that education is less discriminatory as regards access to employment there. Overall, women have ceteris paribus a lower probability of being employed, especially in France, as can be seen from the effect of the female dummy. In both countries, however, the positive and significant effect of the female-education interactions indicate that education has more discriminatory power for women than for men in terms of access to employment. Moreover, the coefficients of the interactions are larger in magnitude for France than for Germany. Thus, being a woman reduces more strongly the employment propensity in France than in Germany, but education increases it more for French than for German women ${ }^{9}$. In particular, French women with a university degree of upper tertiary level (level 41) are much more likely to be in paid employment than more poorly educated women.

Not only does education play a role in terms of average propensity of working, but also in terms of unexplained dispersion of this work propensity, after observable characteristics have been controlled for. Here, the effects are very much different different for men and women (see bottom of table 3). For men, attaining a higher level

8 The test used here is the $R^{2}$ of an estimation of the inverse Mill's ratio (computed as $\left.\phi\left(z_{i} \gamma / \sigma_{2 i}\right) / \Phi\left(z_{i} \gamma / \sigma_{2 i}\right)\right)$ on the regressors of the earnings equation. If the $R^{2}$ appears to be too high (at levels above 0.70 for instance), this is an indication of the weakness of the exclusion restrictions.

9 Note that the relative educational attainment of women compared to men is better in France than in Germany, which contributes to explaining that the labour force participation of women is overall higher in France than in Germany. 
Table 3: Determinants of selection into paid employment

\begin{tabular}{|c|c|c|c|c|}
\hline \multirow[b]{2}{*}{ Variable } & \multicolumn{2}{|c|}{ Germany } & \multicolumn{2}{|c|}{ France } \\
\hline & coef. & (s.e) & coef. & (s.e) \\
\hline \multicolumn{5}{|l|}{ Mean effects $(\gamma)$ : } \\
\hline \multicolumn{5}{|l|}{ Education (ref.: Level 10 or 11) } \\
\hline Level 12 & -0.07 & $(0.07)$ & $0.08^{* *}$ & $(0.03)$ \\
\hline Level 20 & $0.34^{* *}$ & $(0.09)$ & 0.00 & $(0.01)$ \\
\hline Level 21 & $0.29^{* *}$ & $(0.10)$ & $0.09^{* *}$ & $(0.02)$ \\
\hline Level 30 & $0.39^{* *}$ & $(0.11)$ & 0.00 & $(0.04)$ \\
\hline Level 31 & 0.18 & $(0.11)$ & $0.09^{*}$ & $(0.04)$ \\
\hline Level 32 & -0.37 & $(1.25)$ & $0.11^{* *}$ & $(0.04)$ \\
\hline Level 33 & $0.64^{*}$ & $(0.25)$ & 0.08 & $(0.09)$ \\
\hline Level 40 & $0.75^{* *}$ & $(0.18)$ & $0.34^{* *}$ & $(0.04)$ \\
\hline Level 41 & $0.86^{* *}$ & $(0.22)$ & $0.16^{* *}$ & $(0.02)$ \\
\hline Female $*$ Level 12 & $1.20^{* *}$ & $(0.12)$ & $0.21^{* *}$ & $(0.03)$ \\
\hline Female ${ }^{*}$ Level 20 & 0.11 & $(0.09)$ & $0.23^{* *}$ & $(0.01)$ \\
\hline Female ${ }^{*}$ Level 21 & $0.46^{* *}$ & $(0.10)$ & $0.32^{* *}$ & $(0.02)$ \\
\hline Female * Level 30 & $0.55^{* *}$ & $(0.12)$ & $0.36^{* *}$ & $(0.04)$ \\
\hline Female $*$ Level 31 & $0.42^{* *}$ & $(0.13)$ & $0.50^{* *}$ & $(0.04)$ \\
\hline Female * Level 32 & 0.24 & $(2.27)$ & $0.35^{* *}$ & $(0.04)$ \\
\hline Female $*$ Level 33 & 0.07 & $(0.30)$ & $0.48^{* *}$ & $(0.10)$ \\
\hline Female ${ }^{*}$ Level 40 & $0.61^{* *}$ & $(0.21)$ & $0.49^{* *}$ & $(0.05)$ \\
\hline Female ${ }^{*}$ Level 41 & 0.14 & $(0.21)$ & $1.00^{* *}$ & $(0.04)$ \\
\hline Female & $-1.61^{* *}$ & $(0.50)$ & $-2.75^{* *}$ & $(0.10)$ \\
\hline \multicolumn{5}{|l|}{ Age and marital status } \\
\hline Age/10 & $0.24^{\dagger}$ & $(0.12)$ & $0.13^{* *}$ & $(0.04)$ \\
\hline Age squared/100 & $-0.07^{* *}$ & $(0.02)$ & $-0.01^{*}$ & $(0.00)$ \\
\hline Female $*$ Age $/ 10$ & $1.06^{* *}$ & $(0.27)$ & $1.23^{* *}$ & $(0.05)$ \\
\hline Female $*$ Age squared/100 & $-0.14^{* *}$ & $(0.03)$ & $-0.16^{* *}$ & $(0.01)$ \\
\hline Married & $0.13^{* *}$ & $(0.04)$ & $0.22^{* *}$ & $(0.01)$ \\
\hline Female $*$ Married & $-0.55^{* *}$ & $(0.08)$ & $-0.42^{* *}$ & $(0.01)$ \\
\hline \multicolumn{5}{|c|}{ Number and age of children (ref.: No children) } \\
\hline One child aged 6-17 & -0.05 & $(0.04)$ & $0.04^{* *}$ & $(0.01)$ \\
\hline One child aged 3-5 & -0.06 & $(0.06)$ & $0.05^{* *}$ & $(0.01)$ \\
\hline One child aged $0-2$ & -0.09 & $(0.06)$ & $0.09^{* *}$ & $(0.01)$ \\
\hline Two children, youngest $6-17$ & -0.07 & $(0.05)$ & $0.04^{* *}$ & $(0.01)$ \\
\hline Two children, youngest $3-5$ & 0.00 & $(0.06)$ & $0.07^{* *}$ & $(0.01)$ \\
\hline Two children, youngest $0-2$ & 0.02 & $(0.07)$ & $0.09^{* *}$ & $(0.01)$ \\
\hline More children, youngest $6-17$ & $-0.22^{* *}$ & $(0.08)$ & $0.07^{* *}$ & $(0.01)$ \\
\hline More children, youngest 3-5 & $-0.23^{* *}$ & $(0.09)$ & $0.06^{* *}$ & $(0.02)$ \\
\hline More children, youngest 0-2 & $-0.26^{* *}$ & $(0.09)$ & $0.09^{* *}$ & $(0.02)$ \\
\hline Female $*$ One child aged $6-17$ & $-0.48^{* *}$ & $(0.07)$ & $-0.13^{* *}$ & $(0.01)$ \\
\hline Female * One child aged $3-5$ & $-1.10^{* *}$ & $(0.13)$ & $-0.17^{* *}$ & $(0.02)$ \\
\hline
\end{tabular}




\begin{tabular}{|c|c|c|c|c|}
\hline \multirow[b]{2}{*}{ Variable } & \multicolumn{2}{|c|}{ Germany } & \multicolumn{2}{|c|}{ France } \\
\hline & coef. & (s.e) & coef. & (s.e) \\
\hline Female $*$ One child aged $0-2$ & $-2.22^{* *}$ & $(0.22)$ & $-0.29^{* *}$ & $(0.02)$ \\
\hline Female $^{*}$ Two children, youngest $6-17$ & $-0.77^{* *}$ & $(0.10)$ & $-0.27^{* *}$ & $(0.01)$ \\
\hline Female $*$ Two children, youngest $3-5$ & $-1.66^{* *}$ & $(0.17)$ & $-0.43^{* *}$ & $(0.02)$ \\
\hline Female $*$ Two children, youngest $0-2$ & $-2.86^{* *}$ & $(0.27)$ & $-0.68^{* *}$ & $(0.02)$ \\
\hline Female ${ }^{*}$ More children, youngest $6-17$ & $-1.26^{* *}$ & $(0.16)$ & $-0.71^{* *}$ & $(0.02)$ \\
\hline Female $*$ More children, youngest $3-5$ & $-1.91^{* *}$ & $(0.22)$ & $-0.97^{* *}$ & $(0.03)$ \\
\hline Female $*$ More children, youngest $0-2$ & $-2.88^{* *}$ & $(0.31)$ & $-1.26^{* *}$ & $(0.04)$ \\
\hline \multicolumn{5}{|l|}{ Partner's education (ref.: Level 1) } \\
\hline Level 2 & $0.06^{*}$ & $(0.03)$ & $0.03^{* *}$ & $(0.01)$ \\
\hline Level 3 & 0.04 & $(0.03)$ & $-0.06^{* *}$ & $(0.01)$ \\
\hline Level 4 & $-0.08^{\dagger}$ & $(0.04)$ & $-0.12^{* *}$ & $(0.01)$ \\
\hline Female $*$ Level 2 & & & $-0.02^{\dagger}$ & $(0.01)$ \\
\hline Female $*$ Level 3 & & & 0.01 & $(0.01)$ \\
\hline Female * Level 4 & & & $-0.08^{* *}$ & $(0.01)$ \\
\hline \multicolumn{5}{|l|}{ Partner's earnings } \\
\hline Gross monthly earnings $/ 1,000$ & 0.01 & $(0.02)$ & $0.02^{* *}$ & $(0.00)$ \\
\hline Female $*$ Gross monthly earnings $/ 1,000$ & $-0.05^{* *}$ & $(0.02)$ & $-0.02^{* *}$ & $(0.00)$ \\
\hline No information on partner's earnings & $-1.05^{* *}$ & $(0.09)$ & $-0.45^{* *}$ & $(0.01)$ \\
\hline \multicolumn{5}{|l|}{ Ownership status (ref.: Not owner) } \\
\hline Owner & $0.19^{* *}$ & $(0.03)$ & $0.04^{* *}$ & $(0.01)$ \\
\hline Female $*$ Owner & $-0.31^{* *}$ & $(0.05)$ & $-0.15^{* *}$ & $(0.01)$ \\
\hline \multicolumn{5}{|l|}{ City size (ref.: <20.000 inh.) } \\
\hline $20-100,000$ inhabitants & $0.14^{* *}$ & $(0.03)$ & $0.15^{* *}$ & $(0.01)$ \\
\hline$\geq 100,000$ inhabitants & $0.14^{* *}$ & $(0.03)$ & $0.20^{* *}$ & $(0.01)$ \\
\hline Female $* 20-100,000$ inhabitants & $-0.22^{* *}$ & $(0.05)$ & $-0.06^{* *}$ & $(0.01)$ \\
\hline Female $* \geq 100,000$ inhabitants & $-0.12^{*}$ & $(0.05)$ & $-0.04^{* *}$ & $(0.01)$ \\
\hline \multicolumn{5}{|l|}{ Current quarter (ref.: 1st quarter) } \\
\hline 2nd quarter & $-0.20^{* *}$ & $(0.03)$ & $-0.11^{* *}$ & $(0.02)$ \\
\hline $3 \mathrm{rd} / 4$ th quarter & $-0.35^{* *}$ & $(0.04)$ & & \\
\hline Female $* 2$ nd quarter & & & $0.19^{* *}$ & $(0.03)$ \\
\hline \multicolumn{5}{|l|}{ Year (ref.: 2000) } \\
\hline 1991 & $0.46^{* *}$ & $(0.05)$ & $-0.08^{* *}$ & $(0.01)$ \\
\hline 1992 & $0.43^{* *}$ & $(0.05)$ & $-0.08^{* *}$ & $(0.01)$ \\
\hline 1993 & $0.49^{* *}$ & $(0.06)$ & $-0.09^{* *}$ & $(0.01)$ \\
\hline 1994 & $0.47^{* *}$ & $(0.05)$ & $-0.09^{* *}$ & $(0.01)$ \\
\hline 1995 & $0.43^{* *}$ & $(0.05)$ & $-0.08^{* *}$ & $(0.01)$ \\
\hline 1996 & $0.46^{* *}$ & $(0.05)$ & $-0.08^{* *}$ & $(0.01)$ \\
\hline 1997 & $0.45^{* *}$ & $(0.05)$ & $-0.08^{* *}$ & $(0.01)$ \\
\hline 1998 & $0.45^{* *}$ & $(0.05)$ & $-0.06^{* *}$ & $(0.01)$ \\
\hline 1999 & $0.53^{* *}$ & $(0.06)$ & $-0.06^{* *}$ & $(0.01)$ \\
\hline
\end{tabular}




\begin{tabular}{|c|c|c|c|c|}
\hline \multirow[b]{2}{*}{ Variable } & \multicolumn{2}{|c|}{ Germany } & \multicolumn{2}{|c|}{ France } \\
\hline & coef. & $(\mathrm{s.e})$ & coef. & (s.e) \\
\hline Female $^{*} 1991$ & & & 0.00 & $(0.02)$ \\
\hline Female * 1992 & & & 0.02 & $(0.02)$ \\
\hline Female $^{*} 1993$ & & & $0.05^{* *}$ & $(0.02)$ \\
\hline Female $^{*} 1994$ & & & $0.05^{* *}$ & $(0.02)$ \\
\hline Female $* 1995$ & & & $0.04^{*}$ & $(0.02)$ \\
\hline Female $^{*} 1996$ & & & $0.05^{* *}$ & $(0.02)$ \\
\hline Female $* 1997$ & & & $0.03^{\dagger}$ & $(0.02)$ \\
\hline Female $^{*} 1998$ & & & 0.02 & $(0.02)$ \\
\hline Female $^{*} 1999$ & & & $0.03^{\dagger}$ & $(0.02)$ \\
\hline Constant & -0.04 & $(0.35)$ & $1.10^{* *}$ & $(0.07)$ \\
\hline \multicolumn{5}{|c|}{ Dispersion effects $\left(\gamma^{h}\right)$ : } \\
\hline \multicolumn{5}{|c|}{ Education (ref.: Level 10 or 11) } \\
\hline Level 12 & $-0.86^{* *}$ & $(0.20)$ & $0.60^{* *}$ & $(0.08)$ \\
\hline Level 20 & $0.45^{*}$ & $(0.18)$ & 0.02 & $(0.04)$ \\
\hline Level 21 & 0.25 & $(0.21)$ & $0.42^{* *}$ & $(0.07)$ \\
\hline Level 30 & $0.52^{*}$ & $(0.21)$ & $0.67^{* *}$ & $(0.14)$ \\
\hline Level 31 & 0.04 & $(0.26)$ & $0.51^{* *}$ & $(0.10)$ \\
\hline Level 32 & 2.58 & $(5.31)$ & $0.93^{* *}$ & $(0.12)$ \\
\hline Level 33 & $1.06^{*}$ & $(0.43)$ & $0.96^{* *}$ & $(0.28)$ \\
\hline Level 40 & $0.78^{* *}$ & $(0.29)$ & $1.08^{* *}$ & $(0.09)$ \\
\hline Level 41 & $1.11^{* *}$ & $(0.31)$ & $0.73^{* *}$ & $(0.07)$ \\
\hline Female $^{*}$ Level 12 & $0.78^{* *}$ & $(0.27)$ & $-0.51^{* *}$ & $(0.09)$ \\
\hline Female $^{*}$ Level 20 & $-1.01^{* *}$ & $(0.22)$ & $-0.09^{\dagger}$ & $(0.05)$ \\
\hline Female ${ }^{*}$ Level 21 & $-0.97^{* *}$ & $(0.24)$ & $-0.35^{* *}$ & $(0.08)$ \\
\hline Female $^{*}$ Level 30 & $-0.82^{* *}$ & $(0.26)$ & $-0.74^{* *}$ & $(0.17)$ \\
\hline Female $^{*}$ Level 31 & -0.10 & $(0.32)$ & $-0.34^{* *}$ & $(0.12)$ \\
\hline Female $^{*}$ Level 32 & -1.74 & $(5.33)$ & $-0.67^{* *}$ & $(0.13)$ \\
\hline Female $^{*}$ Level 33 & $-1.04^{*}$ & $(0.46)$ & -0.46 & $(0.31)$ \\
\hline Female $^{*}$ Level 40 & -0.46 & $(0.37)$ & $-0.30^{* *}$ & $(0.10)$ \\
\hline Female $^{*}$ Level 41 & $-0.62^{\dagger}$ & $(0.35)$ & $-0.55^{* *}$ & $(0.10)$ \\
\hline Female & $0.97^{* *}$ & $(0.21)$ & $0.34^{* *}$ & $(0.05)$ \\
\hline Age/10 & 0.01 & $(0.02)$ & $-0.06^{* *}$ & $(0.01)$ \\
\hline Trend & $-0.02^{* *}$ & $(0.00)$ & $0.01^{* *}$ & $(0.00)$ \\
\hline \multicolumn{5}{|c|}{ Correlation between selection and earnings equation $(o)$ : } \\
\hline Female & $-0.25^{* *}$ & $(0.06)$ & $-0.14^{* *}$ & $(0.02)$ \\
\hline Male & $-0.57^{* *}$ & $(0.06)$ & $-0.40^{* *}$ & $(0.01)$ \\
\hline \multicolumn{5}{|l|}{ Tests on correlation } \\
\hline$\varrho:$ Male $=$ Female & 14.89 & $(0.00)$ & 154.10 & $(0.00)$ \\
\hline$\varrho=0$ & 97.60 & $(0.00)$ & $1,318.85$ & $(0.00)$ \\
\hline
\end{tabular}


of educational attainment increases the unexplained dispersion in the participation propensity, everything else being equal. This is true in both France and Germany. In particular, men with an education level beyond the maturity certificate have a significantly higher residual dispersion in employment participation than more poorly educated men. Being a woman is associated with a higher unexplained dispersion of the propensity of working compared to men, especially in Germany. However, contrary to men, attaining a higher level of educational attainment reduces the unexplained dispersion in the work propensity among women.

To sum up, selectivity is at work and the selection process is affected by the education level. If the selection into paid employment proved not to have an impact on the estimates determinants of earnings, then, the earnings equation could (and should, for efficiency reasons) be estimated on its own. As is reported at the bottom of table 3 , the hypothesis that the correlation $\varrho$ between the unobserved factors of the selection and the earnings equations is zero, i.e. the hypothesis that there is no selectivity effect, is strongly rejected. Thus, it is important to model the selection into employment together with the earnings, otherwise the coefficients might be biased. Moreover, the correlation between selection into paid employment and earnings was allowed to differ between men and women, since there is no a priori reason to assume that the correlation with earnings should be the same for men and women. As a matter of fact, a further test shows that the correlation does differ for men and women. This is why a gender specific correlation term has been estimated for both countries. The correlation proves to be highly significant and negative for both men and women and stronger for women than for men in both countries.

Given that there is evidence of selectivity effects affecting the determination of earnings, the question which arises now is whether this selectivity affects the estimates of the effects of education on earnings. To address this issue, the earnings equation has been estimated again without correcting for selectivity bias ${ }^{10}$. Then, the average earnings premia and the earnings dispersion effects of education, as well as their standard errors have been computed as explained in section 3.2 on the basis of the coefficients of the earnings equation estimated without correcting for selectivity bias. The estimated average earnings premia and earnings dispersion effects of education with and without correction for selectivity are reported in table 8 in the appendix and the difference between them indicates the extent to which the selectivity bias affects these estimates.

As can be seen, even if selectivity does not affect much the qualitative interpretation of the results, it has an impact on the magnitude of the estimates. The estimated earnings premia for education are slightly higher when one does not correct for the selectivity bias due to non-random selection into paid employment. For France, however, the difference is rather small, especially for men. For Germany, the difference is a little bit higher, but this is also because the estimates are somewhat less precise due to a smaller number of observations. The effect of education on earnings disper-

10 Results available upon request. 
sion also tend to be larger when omitting to correct for the selectivity bias. Here, however, the effect is more marked for men than for women in both countries. The following results are based on the selectivity-corrected equations since these are the correct ones.

\section{The earnings premium for education}

As for the selection equation, the first step consisted here also in determining which variables should be included in the earnings equation. To this end, the statistical significance of the variables has been tested in a systematic way. Here again, only the results of the joint tests are reported in table 7 in the appendix, whereas the test results on the the statistical significance of separate variables appear directly in the results table 4 . The impact on earnings of almost all explanatory variables differs significantly across genders. The hypothesis of a homoscedastic variance of earnings is strongly rejected for both countries. In particular, it appears that the level of educational attainment does not only affect the expected level of earnings, but also the dispersion of earnings, and this in a different way for men and women.

Table 4 reports the whole estimation results of the earnings equation. The next sections will present in detail the effect of education, differentiating between men and women, both in terms of level (section 6.1) and in terms of dispersion (6.2). The impact of the variables other than education can be read from the table and will not be further commented here, since this is not the primary focus of this study.

\subsection{Effect of education in terms of earnings level}

In this part, the mean effect of education on earnings - called here the average earnings premium $A E P$-is examined, drawing on the coefficients estimated and presented in table 4 as explained in section 3.2. The aim is here to find out how much additional earnings is associated, on average, with the attainment of a higher level of education, if anything else is equal. The exact figures computed for each element of $A E P$ and $S E(A E P)$ for men, women and altogether, based on the estimates obtained from the selectivity-corrected earnings equation are given in table 8 in the appendix ${ }^{11}$. For illustration purposes, the average earnings premium for education is represented graphically here (please consult table 8 to see the standard errors of the estimated earnings premia).

Figure 3 pictures the average earnings premia for the various education levels in France and Germany, irrespective of gender, calculated on the basis of equation (15). As can be seen, attaining a higher education level than the reference level yields a positive earnings premium in both countries. Though broadly speaking, the higher the education level, the higher the reward in terms of earnings, the educationearnings link is not monotonous. Looking into detail, one can see that a level 20

11 For comparison, the estimates computed on the basis of the regression without selectivity correction have been reported too. 
Table 4: Determinants of earnings (corrected for selectivity)

\begin{tabular}{|c|c|c|c|c|}
\hline \multirow[b]{2}{*}{ Variable } & \multicolumn{2}{|c|}{ Germany } & \multicolumn{2}{|c|}{ France } \\
\hline & coef. & (s.e) & coef. & (s.e) \\
\hline \multicolumn{5}{|l|}{ Mean effects $(\beta)$ : } \\
\hline \multicolumn{5}{|l|}{ Education (ref.: Level 10 or 11) } \\
\hline Level 12 & $0.13^{* *}$ & $(0.03)$ & $0.18^{* *}$ & $(0.00)$ \\
\hline Level 20 & $0.05^{* *}$ & $(0.01)$ & $0.09^{* *}$ & $(0.00)$ \\
\hline Level 21 & $0.21^{* *}$ & $(0.01)$ & $0.17^{* *}$ & $(0.00)$ \\
\hline Level 30 & $0.17^{* *}$ & $(0.01)$ & $0.28^{* *}$ & $(0.01)$ \\
\hline Level 31 & $0.17^{* *}$ & $(0.02)$ & $0.27^{* *}$ & $(0.00)$ \\
\hline Level 32 & 0.06 & $(0.08)$ & $0.32^{* *}$ & $(0.01)$ \\
\hline Level 33 & $0.13^{* *}$ & $(0.02)$ & $0.29^{* *}$ & $(0.01)$ \\
\hline Level 40 & $0.43^{* *}$ & $(0.02)$ & $0.41^{* *}$ & $(0.00)$ \\
\hline Level 41 & $0.51^{* *}$ & $(0.02)$ & $0.70^{* *}$ & $(0.00)$ \\
\hline Female $^{*}$ Level 12 & $0.06^{\dagger}$ & $(0.04)$ & $-0.02^{* *}$ & $(0.01)$ \\
\hline Female $^{*}$ Level 20 & $0.12^{* *}$ & $(0.02)$ & $0.01^{* *}$ & $(0.00)$ \\
\hline Female $*$ Level 21 & $0.08^{* *}$ & $(0.02)$ & $0.01^{\dagger}$ & $(0.01)$ \\
\hline Female $^{*}$ Level 30 & $0.10^{* *}$ & $(0.02)$ & 0.01 & $(0.01)$ \\
\hline Female $*$ Level 31 & $0.07^{*}$ & $(0.03)$ & 0.00 & $(0.01)$ \\
\hline Female $*$ Level 32 & $0.31^{* *}$ & $(0.10)$ & 0.01 & $(0.01)$ \\
\hline Female $^{*}$ Level 33 & $0.23^{* *}$ & $(0.03)$ & 0.01 & $(0.01)$ \\
\hline Female $^{*}$ Level 40 & 0.03 & $(0.03)$ & $0.08^{* *}$ & $(0.01)$ \\
\hline Female $^{*}$ Level 41 & $0.08^{* *}$ & $(0.03)$ & $0.03^{* *}$ & $(0.01)$ \\
\hline Female & $-0.52^{* *}$ & $(0.10)$ & $0.13^{* *}$ & $(0.03)$ \\
\hline Age/10 & $0.41^{* *}$ & $(0.03)$ & $0.34^{* *}$ & $(0.01)$ \\
\hline Age squared/100 & $-0.04^{* *}$ & $(0.00)$ & $-0.03^{* *}$ & $(0.00)$ \\
\hline Female $*$ Age $/ 10$ & 0.03 & $(0.05)$ & $-0.18^{* *}$ & $(0.01)$ \\
\hline Female $*$ Age squared/100 & -0.01 & $(0.01)$ & $0.02^{* *}$ & $(0.00)$ \\
\hline Tenure/10 & $0.11^{* *}$ & $(0.01)$ & $0.13^{* *}$ & $(0.00)$ \\
\hline Tenure squared/100 & $-0.02^{* *}$ & $(0.00)$ & $-0.02^{* *}$ & $(0.00)$ \\
\hline Female ${ }^{*}$ Tenure $/ 10$ & $0.04^{*}$ & $(0.02)$ & $0.07^{* *}$ & $(0.00)$ \\
\hline Female $*$ Tenure squared/100 & $-0.01^{*}$ & $(0.01)$ & $-0.00^{* *}$ & $(0.00)$ \\
\hline Firm size (ref.: <5 employees) & & & & \\
\hline 5-19 employees & $0.14^{* *}$ & $(0.01)$ & $-0.04^{* *}$ & $(0.00)$ \\
\hline 20-199 employees & $0.23^{* *}$ & $(0.01)$ & $-0.01^{* *}$ & $(0.00)$ \\
\hline 200-1999 employees & $0.28^{* *}$ & $(0.01)$ & $0.02^{* *}$ & $(0.00)$ \\
\hline$\geq 2000$ employees & $0.33^{* *}$ & $(0.01)$ & $0.05^{* *}$ & $(0.00)$ \\
\hline Missing information & $0.11^{* *}$ & $(0.04)$ & $0.10^{* *}$ & $(0.00)$ \\
\hline Female $^{*} 5$-19 employees & $0.07^{* *}$ & $(0.02)$ & $0.07^{* *}$ & $(0.00)$ \\
\hline Female $* 20-199$ employees & $0.08^{* *}$ & $(0.02)$ & $0.05^{* *}$ & $(0.00)$ \\
\hline Female $^{*}$ 200-1999 employees & $0.10^{* *}$ & $(0.02)$ & $0.04^{* *}$ & $(0.00)$ \\
\hline Female $^{*} \geq 2000$ employees & $0.11^{* *}$ & $(0.02)$ & $0.03^{* *}$ & $(0.00)$ \\
\hline Female ${ }^{*}$ Missing information & 0.09 & $(0.06)$ & $-0.07^{* *}$ & $(0.01)$ \\
\hline
\end{tabular}




\begin{tabular}{lcccc}
\hline \hline & \multicolumn{2}{c}{ Germany } & \multicolumn{2}{c}{ France } \\
Variable & coef. & (s.e) & coef. & $($ s.e) \\
\hline Industry branch (ref.: Industry or missing) & & & \\
Agriculture, energy & -0.01 & $(0.01)$ & $-0.08^{* *}$ & $(0.00)$ \\
Construction & -0.01 & $(0.01)$ & $-0.06^{* *}$ & $(0.00)$ \\
Trade & $-0.12^{* *}$ & $(0.01)$ & $-0.06^{* *}$ & $(0.00)$ \\
Banking & $0.05^{* *}$ & $(0.01)$ & $0.04^{* *}$ & $(0.00)$ \\
Transports & $-0.16^{* *}$ & $(0.01)$ & $-0.02^{* *}$ & $(0.00)$ \\
Private services & $-0.25^{* *}$ & $(0.03)$ & $-0.05^{* *}$ & $(0.00)$ \\
Public services & $-0.09^{* *}$ & $(0.01)$ & $-0.09^{* *}$ & $(0.00)$ \\
Missing information & -0.02 & $(0.03)$ & $-0.18^{* *}$ & $(0.01)$ \\
Female * Agriculture, energy & -0.04 & $(0.03)$ & $0.02^{* *}$ & $(0.01)$ \\
Female * Construction & -0.01 & $(0.03)$ & $0.06^{* *}$ & $(0.01)$ \\
Female * Trade & $0.03^{*}$ & $(0.01)$ & $0.01^{* *}$ & $(0.00)$ \\
Female * Banking & $0.06^{* *}$ & $(0.02)$ & $0.02^{* *}$ & $(0.01)$ \\
Female * Transports & $0.12^{* *}$ & $(0.02)$ & $0.02^{* *}$ & $(0.01)$ \\
Female * Private services & -0.01 & $(0.03)$ & $-0.03^{* *}$ & $(0.00)$ \\
Female * Public services & $0.17^{* *}$ & $(0.02)$ & $0.04^{* *}$ & $(0.00)$ \\
Female * Missing information & -0.06 & $(0.04)$ & $0.06^{* *}$ & $(0.01)$ \\
Type of employment & & & & \\
Fixed-term contract & & & $t o$ & $b e ~ c o n t i n u e d . .$.
\end{tabular}


..table 4 continued

\begin{tabular}{|c|c|c|c|c|}
\hline \multirow[b]{2}{*}{ Variable } & \multicolumn{2}{|c|}{ Germany } & \multicolumn{2}{|c|}{ France } \\
\hline & coef. & (s.e) & coef. & (s.e) \\
\hline 1992 & $-0.10^{* *}$ & $(0.01)$ & $-0.02^{* *}$ & $(0)$ \\
\hline 1993 & $-0.05^{* *}$ & $(0.01)$ & $0.04^{* *}$ & $(0.00)$ \\
\hline 1994 & $-0.04^{* *}$ & $(0.01)$ & $0.02^{* *}$ & $(0.00)$ \\
\hline 1995 & $0.02^{\dagger}$ & $(0.01)$ & $0.01^{* *}$ & $(0.00)$ \\
\hline 1996 & $0.02^{\dagger}$ & $(0.01)$ & $0.01^{* *}$ & $(0.00)$ \\
\hline 1997 & $-0.03^{* *}$ & $(0.01)$ & $-0.01^{* *}$ & $(0.00)$ \\
\hline 1998 & $-0.04^{* *}$ & $(0.01)$ & $-0.03^{* *}$ & $(0.00)$ \\
\hline 1999 & $-0.02^{*}$ & $(0.01)$ & $-0.02^{* *}$ & $(0.00)$ \\
\hline Female * 1991 & & & 0.00 & $(0.01)$ \\
\hline Female * 1992 & & & 0.00 & $(0.01)$ \\
\hline Female $* 1993$ & & & $-0.01^{* *}$ & $(0.00)$ \\
\hline Female * 1994 & & & $-0.02^{* *}$ & $(0.00)$ \\
\hline Female $^{*} 1995$ & & & $-0.01^{*}$ & $(0.00)$ \\
\hline Female $* 1996$ & & & $-0.01^{\dagger}$ & $(0.00)$ \\
\hline Female $^{*} 1997$ & & & 0.00 & $(0.00)$ \\
\hline Female $^{*} 1998$ & & & -0.01 & $(0.00)$ \\
\hline Female $* 1999$ & & & $0.01^{*}$ & $(0.00)$ \\
\hline Constant & $1.54^{* *}$ & $(0.07)$ & $1.23^{* *}$ & $(0.02)$ \\
\hline \multicolumn{5}{|c|}{ Dispersion effects $\left(\beta^{h}\right)$ : } \\
\hline Education (ref.: Le & & & & \\
\hline Level 12 & $0.13^{*}$ & $(0.06)$ & $0.09^{* *}$ & $(0.01)$ \\
\hline Level 20 & $-0.15^{*}$ & $(0.06)$ & $-0.07^{* *}$ & $(0.01)$ \\
\hline Level 21 & $-0.10^{* *}$ & $(0.04)$ & $-0.05^{* *}$ & $(0.01)$ \\
\hline Level 30 & -0.02 & $(0.07)$ & $0.07^{* *}$ & $(0.03)$ \\
\hline Level 31 & $0.32^{* *}$ & $(0.08)$ & 0.01 & $(0.02)$ \\
\hline Level 32 & $0.53^{* *}$ & $(0.16)$ & $0.34^{* *}$ & $(0.02)$ \\
\hline Level 33 & $0.17^{\dagger}$ & $(0.09)$ & $0.11^{* *}$ & $(0.04)$ \\
\hline Level 40 & $0.30^{* *}$ & $(0.08)$ & $0.08^{* *}$ & $(0.01)$ \\
\hline Level 41 & $0.63^{* *}$ & $(0.07)$ & $0.60^{* *}$ & $(0.01)$ \\
\hline Female $^{*}$ Level 12 & $-0.46^{* *}$ & $(0.15)$ & $-0.08^{* *}$ & $(0.02)$ \\
\hline Female $*$ Level 20 & $-0.40^{* *}$ & $(0.08)$ & $-0.07^{* *}$ & $(0.01)$ \\
\hline Female $^{*}$ Level 21 & $-0.43^{* *}$ & $(0.08)$ & $-0.20^{* *}$ & $(0.02)$ \\
\hline Female $*$ Level 30 & $-0.63^{* *}$ & $(0.09)$ & $-0.40^{* *}$ & $(0.04)$ \\
\hline Female $^{*}$ Level 31 & $-0.93^{* *}$ & $(0.12)$ & $-0.27^{* *}$ & $(0.02)$ \\
\hline Female $^{*}$ Level 32 & $-0.73^{* *}$ & $(0.21)$ & $-0.33^{* *}$ & $(0.02)$ \\
\hline Female $^{*}$ Level 33 & $-0.37^{* *}$ & $(0.11)$ & $-0.32^{* *}$ & $(0.05)$ \\
\hline Female $^{*}$ Level 40 & $-0.44^{* *}$ & $(0.11)$ & $-0.31^{* *}$ & $(0.02)$ \\
\hline Female $^{*}$ Level 41 & $-0.72^{* *}$ & $(0.09)$ & $-0.18^{* *}$ & $(0.02)$ \\
\hline Female & $0.90^{* *}$ & $(0.07)$ & $0.16^{* *}$ & $(0.01)$ \\
\hline Age & $0.07^{* *}$ & $(0.01)$ & $0.19^{* *}$ & $(0.01)$ \\
\hline Trend & $0.02^{* *}$ & $(0.00)$ & $-0.02^{* *}$ & $(0.00)$ \\
\hline Constant & $-2.54^{* *}$ & $(0.06)$ & $-2.20^{* *}$ & $(0.01)$ \\
\hline
\end{tabular}

Significance level : $\quad \dagger: 10 \% \quad *: 5 \% \quad * *: 1 \%$ 
Figure 3: Average earnings premium for education (Ref.: Level 10 or 11)

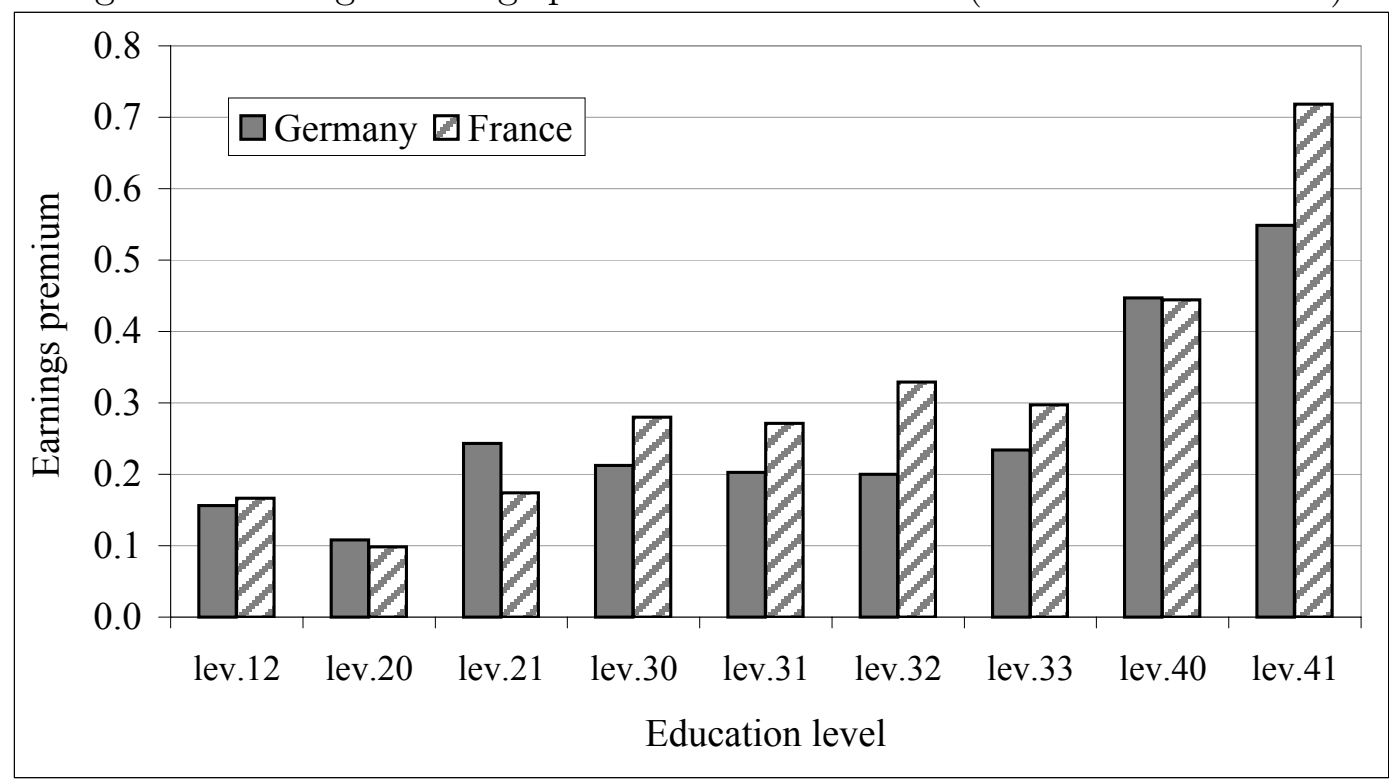

qualification (no or lower secondary education + basic vocational degree) yields a smaller earnings premium than level 12 qualification (intermediate secondary education without any vocational qualification) in Germany and in France alike. Thus, it seems that the employers attach more value to the attainment of a minimum level of general education than to the acquisition of a vocational qualification. A reason for this might be that the quality of the completed vocational training might depend on the level attained in general education or that a minimum level of general education is necessary to show enough learning flexibility on the job. In any case, it is, on average, more worth it in terms of earnings to strive for attaining at least an intermediate level of general education rather than, having a poor general education, to opt for a basic vocational degree.

In France, there is not much difference in the earnings premium for education level 12 and for education level 21, i.e. whether individuals with an intermediate secondary education have or do not have a basic vocational degree. This means that in France a basic vocational degree has some value only if one has an extremely poor level of secondary education (i.e. a basic vocational degree is "better than nothing"), but as soon as one has attained intermediate secondary schooling, this becomes irrelevant. This is different in Germany, where Realschule graduates (i.e. intermediate secondary schooling) enjoy a positive earnings premium for completing a basic vocational qualification, as can be seen from the significantly higher earnings premium for level 21 than for level 12. Thus, the skills provided by the vocational education system seem to be more highly valued by the labour market in Germany than in France. This is confirmed by the observation that basic vocational education (level 2) better leads to a higher earnings premium on average in Germany. Again, this might be explained by the fact that vocational education in Germany is more tightly linked to the needs of the labour market while it remains rather theoretical 
in France and less connected to the job market. In this context, it becomes more essential to reach a minimum level of general education based on which one can train more easily on-the-job.

In Germany, the completion of an intermediate level qualification (level 3 qualifications) does not yield any additional earnings premium. Thus, advanced vocational qualifications bring a further advantage in terms of employment (see Lauer, 2003a), but less so in terms of earnings. By contrast, in France, intermediate vocational qualifications bring about an additional earnings premium compared to basic ones, though it makes no difference if these have the status of a maturity certificate (level 31) or not (level 30). Moreover, unlike in Germany, the completion of the general maturity certificate (Baccalauréat Général, level 32 and 33) as such is rewarded in terms of earnings, though the additional premium obtained for it is rather small. This confirms the well-known high status of the French Baccalauréat.

In both countries, higher education degrees yield a high earnings premium on average, anything else equal. Thus, there is a large gap between the average earnings premium of tertiary level degrees and that of qualifications below this level. Level 40 degrees, i.e. lower tertiary level degrees yield a same reward in France and Germany, though in the classification of educational degrees, the requirement level of these level 40 degrees is lower in France (2 years after Baccalauréat) than in Germany (4 years after (Fach)Hochschulreife). The earnings premium for upper tertiary education is much higher in France than in Germany, though study duration is typically shorter. This is most probably the effect of the presence of the Grandes Ecoles, which comprise about 30 percent of higher education graduates and are specifically designed at meeting the demand of the economy for high level positions.

Let us know have a look at gender differences in the average earnings premium for education. Judging from the coefficient of the female dummy in table 4, women ceteris paribus lower earnings in Germany, whereas it affects earnings positively in France if anything else is hold constant, meaning that for given other characteristics and rewards of these characteristics, French women would perceive slightly higher earnings than their male counterparts on average.

We know that the educational attainment of women is poorer than that of men in Germany and to a lesser extent also in France (Lauer, 2003b). However, looking at figure 4 and figure 5, it appears that, on the whole, a same level of educational attainment is more highly rewarded for women than for men in terms of earnings. This is true in both countries, though the gender gap in the average earnings premium for education is significantly larger in Germany than in France. Particularly in Germany, women are more poorly endowed in human capital - at least as measured by educational attainment - but they enjoy a significantly more favourable reward of their education. The gender gap in the average earnings premium for education does not have the same extent for all education levels. In Germany, women have a higher premium than men for all education levels, but the gap is particularly large for level 32 and level 33, i.e. for holders of the general maturity certificate (Abitur). 
Figure 4: Average earnings premium by gender (Ref.: Level 10 or 11) - Germany

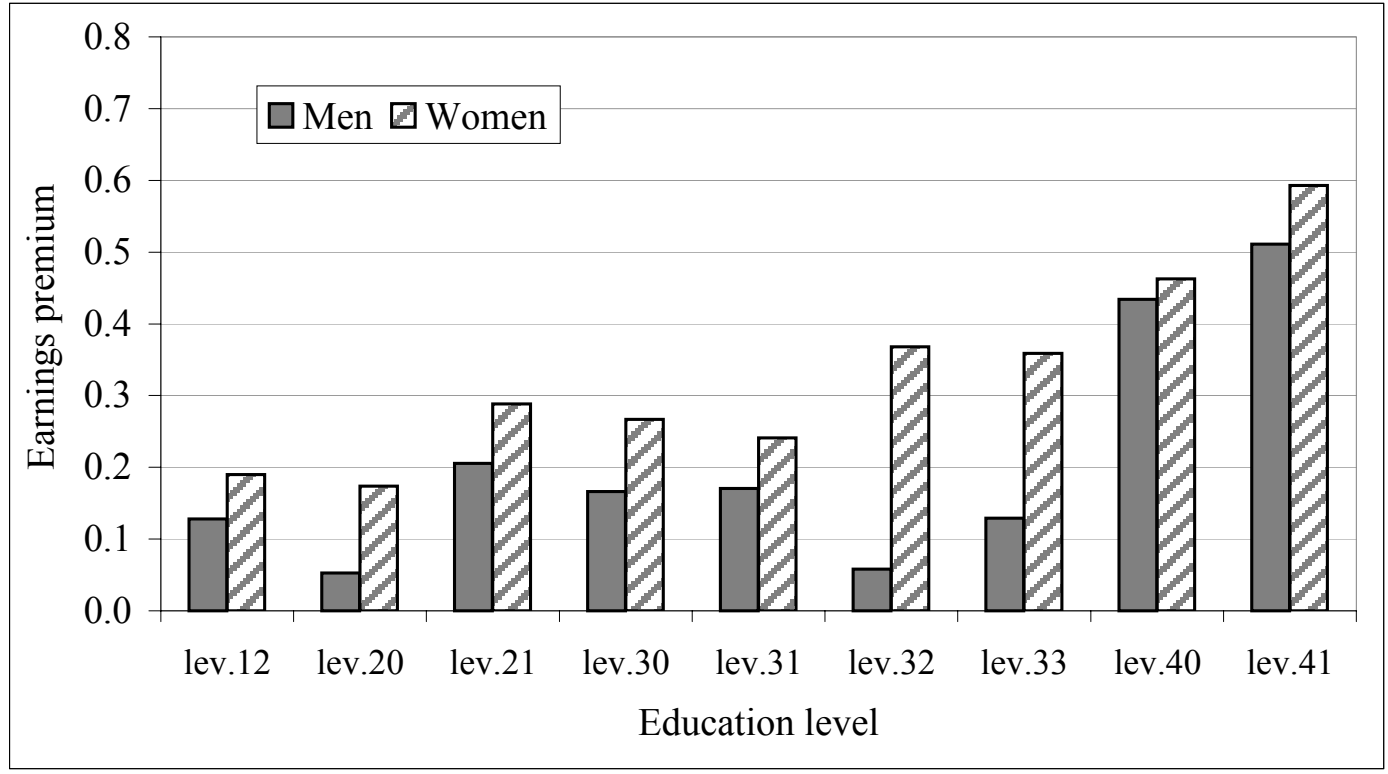

Figure 5: Average earnings premium by gender (Ref.: Level 10 or 11) - France

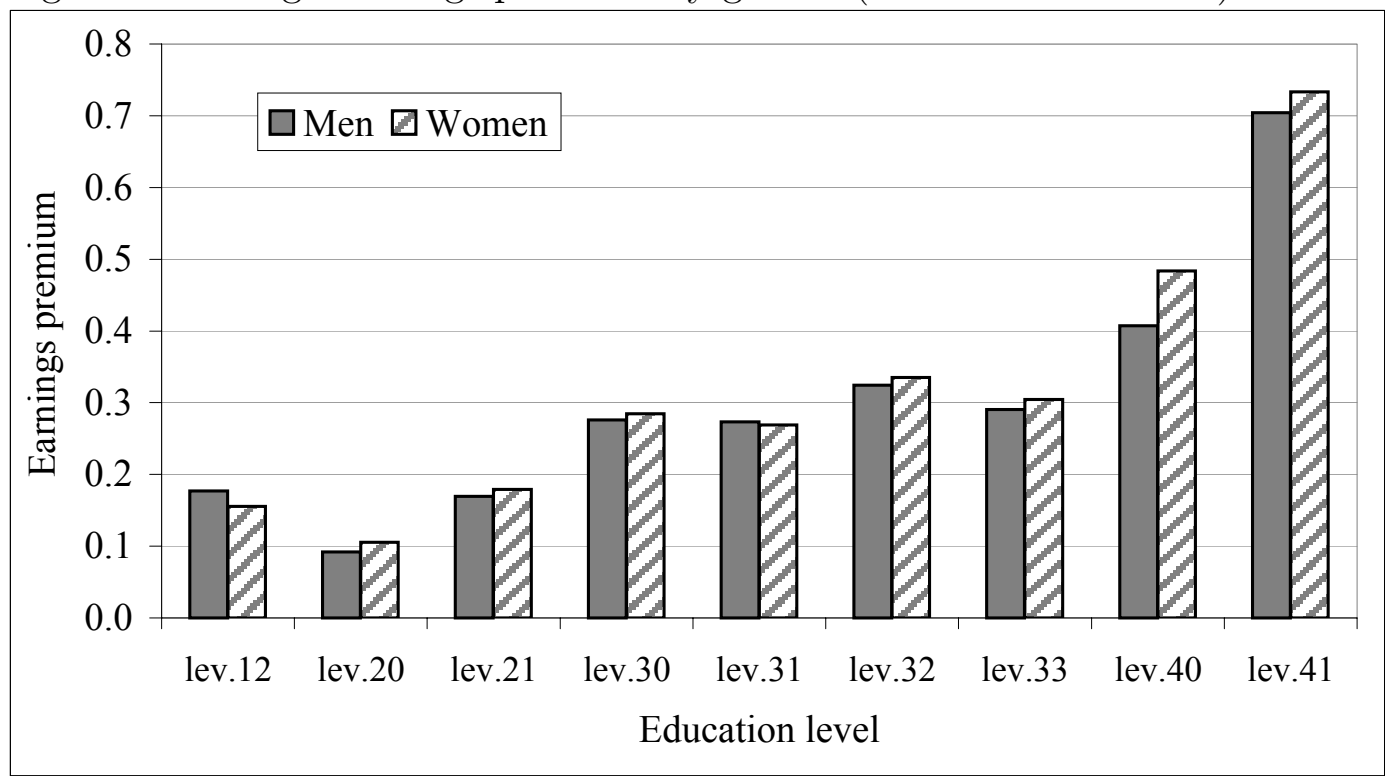

It is much less pronounced for tertiary education graduates. In France, the earnings premia for basic and advanced vocational qualifications are nearly the same for French men and women. However, there is a significant gap in favour of women in the earnings premium for tertiary level qualifications, especially lower tertiary ones. 


\subsection{Effect of education in terms of unexplained earnings dispersion}

The previous section showed what earnings premium can be expected from investing in a certain education level, anything else equal. However, it also matters whether the educational investment also affects the unexplained earnings dispersion to be expected. Indeed, the residual earnings dispersion can be seen as a measure of the remaining earnings uncertainty or earnings risk. As previously, the estimated earnings dispersion effects for each level of educational attainment relative to the reference level 10/11 as well as the associated standard errors are given in table 9 in the appendix. Here, the estimates of the elements of $E D E$ are represented graphically, without the standard errors. Figure 7 shows for France and Germany the effect that is caused, irrespective of gender, by the attainment of a specific education level rather than no or only a low level school degree, computed on the basis of formula (16).

Figure 6: Earnings dispersion effect of education (Ref.: Level 10 or 11)

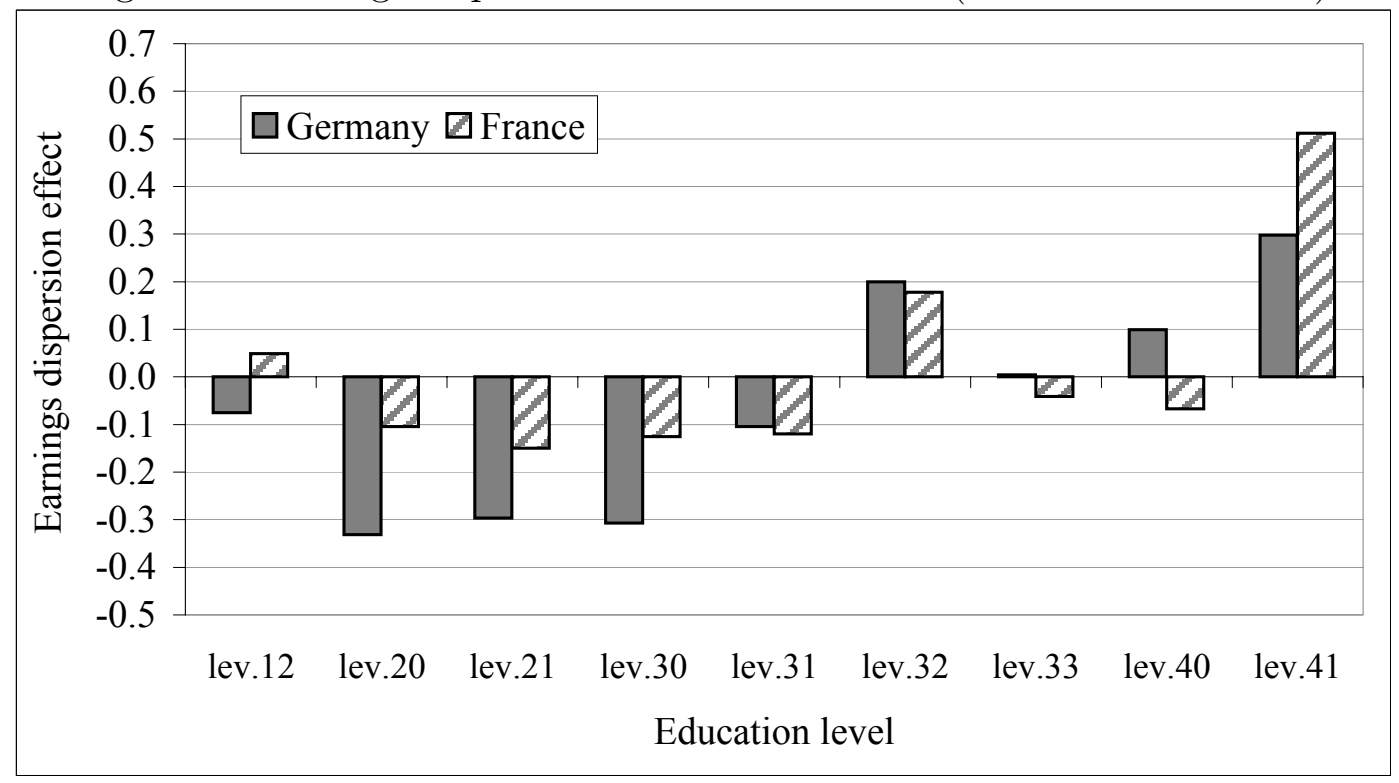

The pattern of earnings dispersion effects of education exhibit some similarities in France and Germany. In both countries, attaining level 12 (i.e. intermediate secondary schooling) has only a small effect, negative ${ }^{12}$ in Germany and positive in France, in terms of earnings dispersion compared to having a poorer education. However, the completion of vocational qualifications (level 20 to level 31) significantly reduces the earnings risk as measured by the residual earnings dispersion. The effects of vocational education on earnings dispersion are larger in magnitude in Germany than in France ${ }^{13}$. Maybe this is because the vocational maturity certificate

12 Judging from the standard error reported in table 9, the small effect found for Germany is hardly significant in statistical terms.

13 Note, however, that the standard errors are also larger. 
is less closely connected to the labour market than dual qualification forms. Thus, the completion of a vocational qualification not only yields an earnings premium, anything else equal, but also reduces the earnings risk significantly, particularly in Germany.

A further commonality is that in France and in Germany alike, individuals having at most the general maturity certificate (level 32) face a comparatively higher earnings dispersion. This might be due to the fact that this qualification level certifies the acquisition of general skills which might lead to very different types of occupations that are likely to bring about different levels of earnings. This interpretation is consistent with the observation that on the whole, no significant effect regarding earnings dispersion, compared to the reference group, is found for those who completed a vocational qualification in addition to the general maturity certificate (level 33): the dispersion-enhancing effect of the general maturity certificate level is offset by the dispersion-reducing effect of a vocational qualification.

In France as in Germany, upper tertiary level graduates are those who face the highest earnings dispersion, especially in France. Interestingly, they face a higher earnings risk than the lower tertiary level graduates. This might be due to the fact that lower tertiary qualifications are typically rather focussed on the needs of the labour market. By contrast, the upper tertiary level includes on the one hand some general study tracks that are not really designed to meet the needs of employers and the graduates of which might experience difficulties in finding a job or at least a well rewarded job. On the other hand, this category also entails those highly skilled workers whose skills are highly demanded by the economy. Thus, the group of upper tertiary level graduates is likely to be a much more heterogeneous group in terms of jobs occupied and this could explain that they face a higher earnings dispersion, even though they have on average the highest earnings premium (see section 6.1).

Let us now examine gender differences in unexplained earnings dispersion and in the impact of education on it. First, the estimation results reported in table 4 show that anything else equal, women face a higher earnings dispersion, judging from the positive and significant effect found for the female dummy in the scedastic function of the earnings equation. Not only do women earn lower earnings on average, these earnings are also less easily predictable. This overall dispersion-enhancing effect of being a women is stronger in Germany than in France. Moreover, in both countries, the level of educational attainment has a different impact on unexplained earnings dispersion for men and for women. As figure 7 and figure 8 show, the gender differences in the earnings dispersion effect of education are substantial in both countries.

In Germany and France alike, the completion of a vocational degree (up to level 31) reduces significantly the unexplained earnings dispersion for women compared to their counterparts with no vocational degree, whereas it is much less so for men, for which the effects observed are very small in scope. This dispersion-reducing effect is much stronger for German than for French women. 
Figure 7: Earnings dispersion effect of education by gender (Ref.: Level 10 or 11) Germany

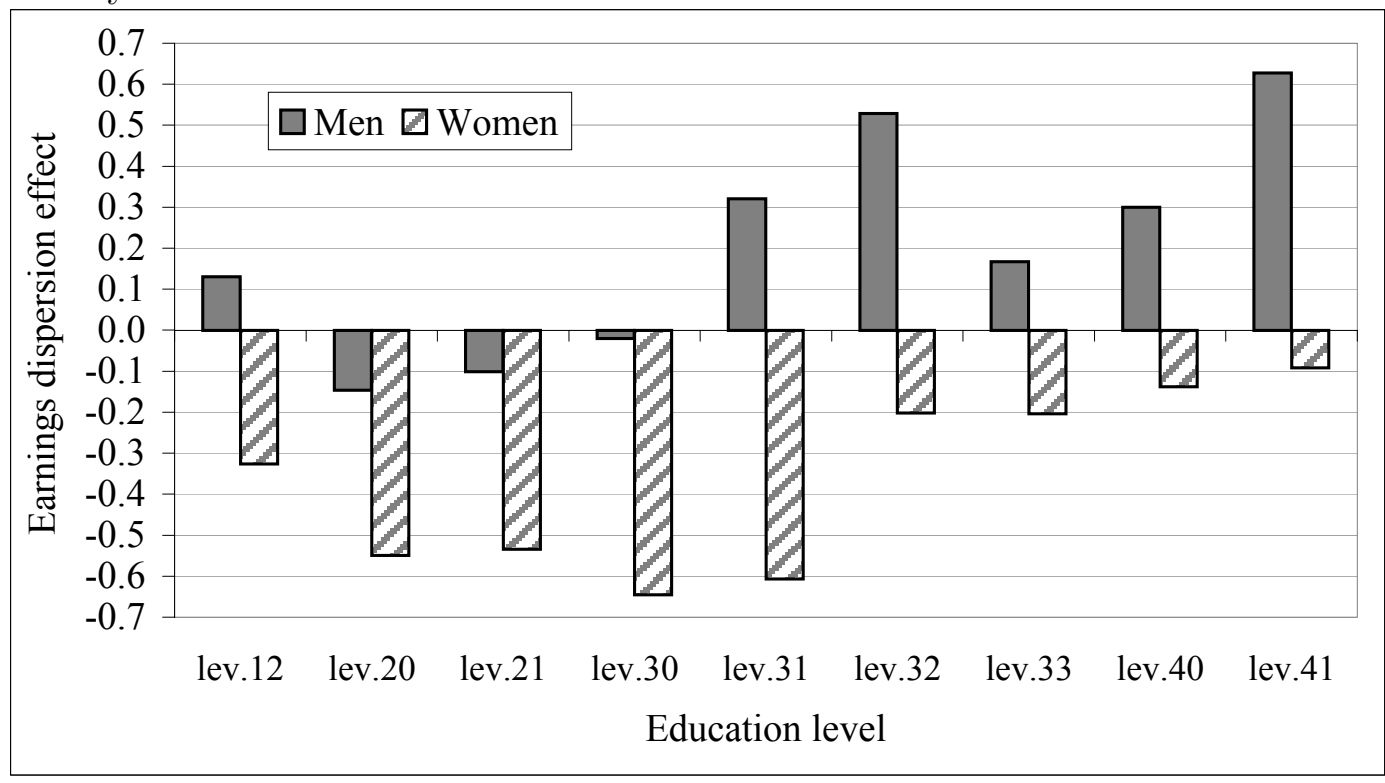

Figure 8: Earnings dispersion effect of education by gender (Ref.: Level 10 or 11) France

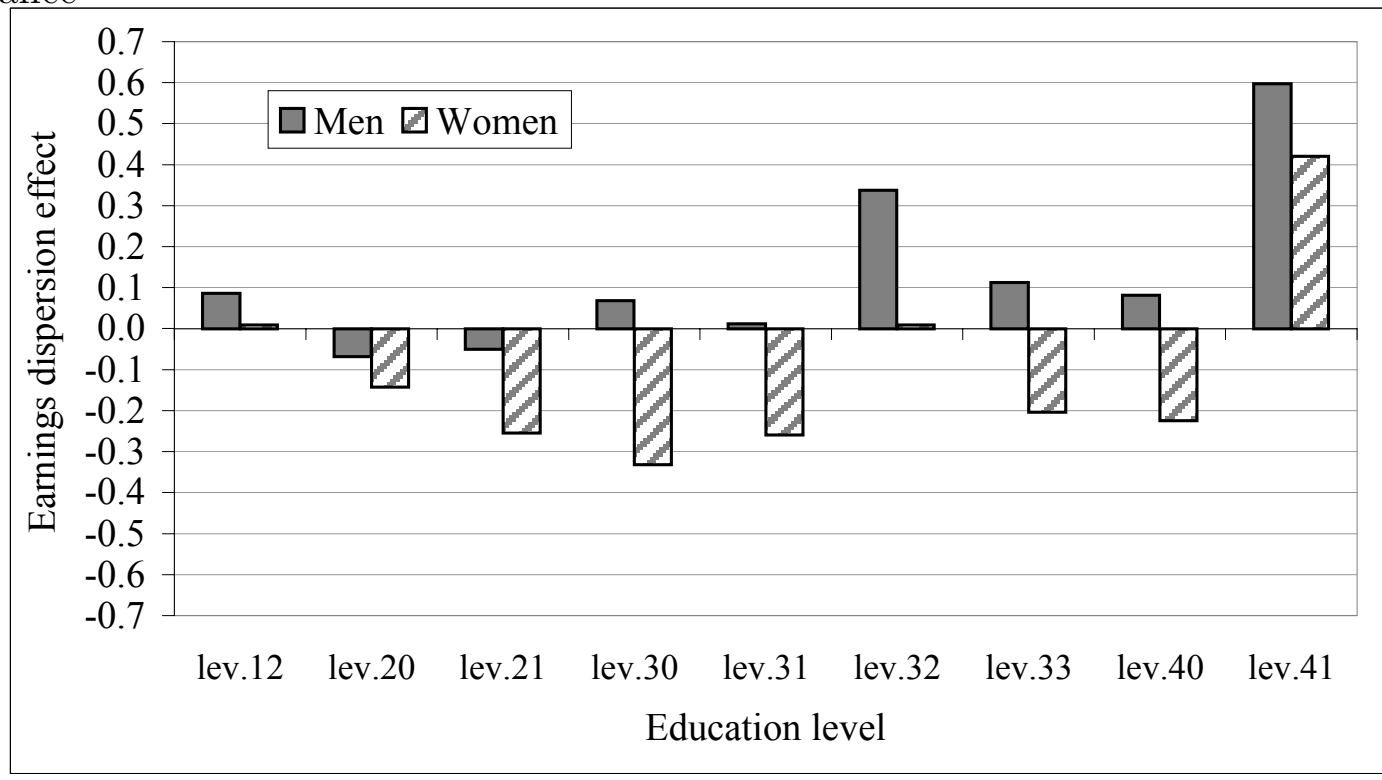

From the general maturity certificate (level 32) onwards, the pattern of earnings dispersion effects changes. For German women, the residual earnings dispersion is still lower than for the reference group of poorly educated women, but only slightly. The higher the educational level attained beside the general maturity certificate, the smaller the earnings dispersion effect. For men, in contrast, the effects go in the opposite direction. Qualifications above the vocational maturity level (level 31) in Germany and above the general maturity level in France (level 32) are associated with a higher earnings dispersion. Interestingly, in both countries, the unexplained 
earnings dispersion is particularly high for male holders of the general maturity certificate and for male university graduates. However, whereas French women also face a strong dispersion enhancing effect of having completed university degree, like their male counterparts though not to the same extent, no such effect is observable in Germany.

On the whole, the attainment of a higher level of education does not only yield a higher earnings premium for women than for men on average, but also lead to a reduction in their earnings risk, if the latter is measured by the earnings dispersion unexplained by the other observable characteristics.

\section{Conclusion}

This study analyses thoroughly the way the qualifications acquired within the French and the German education systems are rewarded in terms of labour market earnings. It first adds to the existing literature through the comparison of France and Germany. The observation of the patterns prevailing both within and across countries enabled to gain new insights on the relationship between education and individual labour market success. A further contribution of this paper is a methodological innovation that makes it possible to assess the impact of educational attainment not only on the expected level of earnings but also on the earnings risk, measured here by the unexplained earnings variance. A look at the literature reveals indeed that even though the link between education and earnings has been extensively analysed internationally following the development of the human capital theory, there is very little comparative work on France and Germany in this area. Moreover, there is very little evidence on the impact of education on earnings dispersion.

First descriptive analyses provide basic descriptive evidence on the correlation between degrees obtained and the earnings level and variance in France and Germany. In order to isolate the effects of education on earnings level and dispersion, however, one has to abstract from other factors that might drive the bivariate relationships observed. The econometric framework developed here aimed to model the impact of education on the expected level of earnings as well as on the residual earnings variance, i.e. the variance of earnings not explained by the explanatory variables, taking into account the non-random and gender-specific selection into paid employment. Indeed, there is evidence that France and Germany differs largely concerning the access to employment, especially for women. To account for gender differences that have different forms in France and Germany, the estimated correlation between the selection propensity and the earnings equation has been allowed to differ for men and women. Moreover, gender differences in the impact of variables on selection and earnings have been tested in a systematic way. To assess the impact of education on earnings uncertainty, the assumption of homoscedastic variances has been relaxed. For both the selection and the earnings equation, the residual variance is assumed to have a multiplicative form of heteroscedasticity and to vary across education levels and genders. 
The key findings can be summarised as follows. First, evidence is found that selectivity effects are at work and differ for men and women. Indeed, there is a significant correlation between the selection and the earnings equation and it differs significantly across genders. Though the bias is not important enough in magnitude to affect much the qualitative interpretation of the results, the estimates of the average earnings premia and earnings dispersion effects of education are affected by the selectivity bias. Though broadly speaking, the level of earnings increases - ceteris paribus - along with educational attainment, anything else constant, the relationship between education and level of earnings is not monotonous when considering detailed levels of education. It appears that in both countries the attainment of a minimum level of general instruction seems to be valued by the employers and cannot be compensated by the completion of a vocational degree. Thus, it seems advisable to concentrate the efforts on fostering the achievement of at least an intermediate level of general instruction.

Second, basic vocational education leads to a higher earnings premium in Germany than in France. This points to the better efficiency of the German system of vocational education compared to the low-status vocational education in France, which remains rather theoretical, less connected to the job market, and signals failure in general education. In Germany, however, there is no additional earnings premium for attaining qualifications at the maturity level, unlike in France, where the completion of the Baccalauréat is rewarded in form of an earnings premium. Finally, the completion of higher education yields a particularly high earnings premium in both countries, but particularly in France, though study duration is typically shorter. This is most probably the effect of the presence of elite institutions in France. Furthermore, in both countries but especially in Germany, women have a lower educational attainment than men but enjoy a higher earnings premium for education, anything else equal. The gender gap in the earnings premium for education is much larger in Germany than in France.

Education is found not only to affect the expected level of earnings, but also the earnings uncertainty, measured by the residual earnings dispersion, after observed factors have been controlled for. Interestingly, the effects of education on the unexplained earnings dispersion or earnings risk is found to present some obvious similarities in France and Germany. In both countries, overall, the completion of vocational qualifications reduces significantly the unexplained earnings dispersion, but the effect is particularly strong in Germany. By contrast, more general qualifications, like the general maturity certificate, are associated with a comparatively stronger earnings dispersion. Upper tertiary level graduates are those who face the highest unexplained earnings dispersion in both countries, particularly in France, due to a larger heterogeneity in the qualifications considered to be of upper tertiary level.

Looking at the effect of gender reveals further common patterns. First, women face overall a higher unexplained earnings dispersion, especially in Germany. Moreover, the effect of education on the residual earnings dispersion appears to differ 
dramatically across genders in both countries. As a matter of facts, the completion of basic or advanced vocational qualifications turns out to reduce substantially the unexplained earnings dispersion for women, particularly for German women, whereas no such effect is observed for men. The attainment of a level of education beyond the maturity level still reduces the earnings risk of women though not to the same extent as vocational qualifications of lower level. For men, by contrast, the attainment of a higher level of education increases the earnings dispersion risk instead of reducing it like for women. Thus, not only do women, on average, enjoy a higher earnings premium than men for investing in education, but it also reduces their earnings risk to a larger extent than for men.

The findings show that only examining the effect of education in terms of earnings level illustrates only one aspect of the relationship between education and earnings. The level of education attained is not neutral with respect to earnings dispersion, even after controlling for gender-specific selection into employment and a large number of explanatory factors. 


\section{References}

Asplund, R. and Pereira, P. T. (1999). Returns to Human Capital in Europe, A Literature Review. Helsinki: Taloustieto Oy.

Becker, G. S. (1964). Human capital: A theoretical and empirical analysis, with special reference to education. New York: Columbia University Press.

Brauns, H., Müller, W. and Steinmann, S. (1997). Educational Expansion and Returns to Education, A Comparative Study on Germany, France, the UK and Hungary (Working Paper No. I/23). MZES.

Card, D. (2000). Estimating the Return to Schooling: Progress on Some Persistent Econometric Problems (Working Paper No. 7769). NBER.

Gould, W. and Sribney, W. (1999). Maximum likelihood estimation with Stata. College Station: Stata Press.

Greene, W. H. (2000). Econometric analysis (4 ed.). London: Prentice Hall International.

Harmon, C., Hogan, V. and Walker, I. (2003). Dispersion in the economic return to education. Labour Economics, 10(2), 205-241.

Heckman, J. J. (1979). Sample selection bias as a specification error. Econometrica, 47, 153-161.

Heckman, J. J., Lochner, L. J. and Todd, P. E. (2003). Fifty years of Mincer earnings regressions (Working Paper No. 9732). NBER.

Kaukewitsch, P. and Rouault, D. (1998). Les structures des salaires en France et en Allemagne en 1995: une analyse statistique comparative des hiérarchies salariales. Economie et Statistique, 315(5), 3-27.

Lauer, C. (2001). Educational Attainment: A French-German Comparison (Documentation No. 01-02). ZEW.

Lauer, C. (2003a). Education and Unemployment: a French-German comparison (Discussion Paper No. 03-34). ZEW.

Lauer, C. (2003b). Family background, cohort and education: A French-German comparison based on a multivariate ordered probit model of educational attainment. Labour Economics, 10, 231-251.

Lauer, C. and Steiner, V. (2001). Germany. In C. Harmon, I. Walker and N. Westergaard-Nielsen (Eds.), Education and Earnings in Europe. A cross country analysis of the returns to education (p. 102-128). Cheltenham (UK): Edward Elgar. 
Lauer, C. and Weber, A. M. (2003). Employment of Mothers After Childbirth: A French-German Comparison (Discussion Paper No. 03-50). ZEW.

Mincer, J. (1974). Schooling, experience, and earnings. New York: NBER.

Pereira, P. T. and Martins, P. S. (2000). Does Education Reduce Wage Inequality? Quantile Regressions Evidence from Fifteen European Countries (Discussion Paper No. 709). ETLA.

Puhani, P. A. (2000). The Heckman correction for sample selection and its critique. Journal of Economic Surveys, 14, 53-68. 


\section{Appendix}

Table 5: Descriptive statistics (sample of simultaneous estimation)

\begin{tabular}{|c|c|c|c|}
\hline & & Germany & France \\
\hline \multirow[t]{10}{*}{ Education level (\%) } & Level 10 or 11 & 11.01 & 28.26 \\
\hline & Level 12 & 3.00 & 7.99 \\
\hline & Level 20 & 31.39 & 20.71 \\
\hline & Level 21 & 17.02 & 10.28 \\
\hline & Level 30 & 11.68 & 1.62 \\
\hline & Level 31 & 4.06 & 4.11 \\
\hline & Level 32 & 1.78 & 5.59 \\
\hline & Level 33 & 5.07 & 0.86 \\
\hline & Level 40 & 4.40 & 10.59 \\
\hline & Level 41 & 10.60 & 10.00 \\
\hline \multicolumn{2}{|l|}{ Female (\%) } & 52.55 & 52.20 \\
\hline \multicolumn{2}{|l|}{ Age (years) } & $\begin{array}{r}39.70 \\
(8.67)\end{array}$ & $\begin{array}{r}39.89 \\
(8.43)\end{array}$ \\
\hline \multicolumn{2}{|l|}{ Married (\%) } & 76.32 & 69.33 \\
\hline \multirow[t]{10}{*}{ Number/age of children (\%) } & No children below 18 & 51.70 & 43.17 \\
\hline & 1 child aged $6-17$ & 15.52 & 16.13 \\
\hline & 1 child aged $3-5$ & 4.21 & 4.07 \\
\hline & 1 child aged $0-2$ & 4.92 & 4.50 \\
\hline & 2 children, youngest $6-17$ & 9.08 & 12.76 \\
\hline & 2 children, youngest $3-5$ & 4.49 & 5.15 \\
\hline & 2 children, youngest $0-2$ & 3.92 & 4.33 \\
\hline & $\geq 3$ children, youngest $6-17$ & 2.25 & 4.22 \\
\hline & $\geq 3$ children, youngest $3-5$ & 2.24 & 3.08 \\
\hline & $\geq 3$ children, youngest $0-2$ & 1.66 & 2.60 \\
\hline \multirow[t]{4}{*}{ Partner's education (\%) } & Level 1 & 14.39 & 36.48 \\
\hline & Level 2 & 47.94 & 31.77 \\
\hline & Level 3 & 22.70 & 12.19 \\
\hline & Level 4 & 14.97 & 19.55 \\
\hline \multicolumn{2}{|c|}{ Partner's gross monthly income (Euros) } & $\begin{array}{l}1,356.37 \\
(169.21)\end{array}$ & $\begin{array}{r}1001.70 \\
(304.34)\end{array}$ \\
\hline \multicolumn{2}{|c|}{ No info on partner's income (\%) } & 18.32 & 27.75 \\
\hline \multicolumn{2}{|c|}{ No partner (\%) } & 11.23 & 17.16 \\
\hline \multicolumn{2}{|l|}{ Owner (\%) } & 48.95 & 59.15 \\
\hline \multirow[t]{3}{*}{ City size (\%) } & $<20.000$ inhabitants & 39.58 & 45.66 \\
\hline & 20-100,000 inhabitants & 27.98 & 13.24 \\
\hline & $\geq 100,000$ inhabitants & 32.45 & 41.10 \\
\hline \multirow[t]{3}{*}{ Current quarter (\%) } & 1st quarter & 65.66 & 98.35 \\
\hline & 2nd quarter & 25.92 & 1.65 \\
\hline & $3 \mathrm{rd} / 4$ th quarter & 8.42 & \\
\hline
\end{tabular}


...table 5 continued

\begin{tabular}{|c|c|c|c|}
\hline & & Germany & France \\
\hline \multirow[t]{10}{*}{ Year $(\%)$} & 1991 & 8.91 & 9.14 \\
\hline & 1992 & 8.69 & 9.45 \\
\hline & 1993 & 8.56 & 9.97 \\
\hline & 1994 & 9.38 & 10.25 \\
\hline & 1995 & 9.81 & 10.24 \\
\hline & 1996 & 9.84 & 10.24 \\
\hline & 1997 & 9.73 & 10.13 \\
\hline & 1998 & 10.70 & 10.19 \\
\hline & 1999 & 10.17 & 10.18 \\
\hline & 2000 & 14.21 & 10.21 \\
\hline \multicolumn{2}{|c|}{ In paid employment (selected, \%) } & 60.06 & 61.86 \\
\hline \multicolumn{2}{|c|}{ Log hourly wage (Euros) } & $\begin{array}{r}2.71 \\
(0.45)\end{array}$ & $\begin{array}{r}2.26 \\
(0.45)\end{array}$ \\
\hline \multicolumn{2}{|l|}{ Tenure (years) } & $\begin{array}{r}10.46 \\
(8.83)\end{array}$ & $\begin{array}{c}11.02 \\
(9.13)\end{array}$ \\
\hline \multirow[t]{6}{*}{ Firm size (\%) } & $<5$ employees & 6.21 & 27.84 \\
\hline & 5-19 employees & 13.11 & 9.85 \\
\hline & 20-199 employees & 25.90 & 15.52 \\
\hline & 200-1999 employees & 24.43 & 20.84 \\
\hline & $\geq 2000$ employees & 28.80 & 20.80 \\
\hline & Missing & 1.55 & 5.16 \\
\hline \multirow[t]{9}{*}{ Industry branch (\%) } & Industry & 32.67 & 20.84 \\
\hline & Agriculture, energy & 2.12 & 3.51 \\
\hline & Construction & 4.43 & 5.21 \\
\hline & Trade & 12.29 & 11.56 \\
\hline & Banking & 8.00 & 4.84 \\
\hline & Transports & 5.44 & 4.73 \\
\hline & Private services & 2.01 & 16.71 \\
\hline & Public services & 30.72 & 31.90 \\
\hline & Missing & 2.32 & 0.71 \\
\hline \multirow[t]{3}{*}{ Type of employment (\%) } & Fixed-term contract & 4.16 & 3.91 \\
\hline & Part-time employment & 20.00 & 17.63 \\
\hline & Public employment & 30.64 & 34.71 \\
\hline \multirow[t]{7}{*}{ Father's occupation (\%) } & Farmer & 4.18 & 11.05 \\
\hline & Self-employed & 6.25 & 10.60 \\
\hline & Senior manager & 10.91 & 7.66 \\
\hline & Middle manager & 15.87 & 11.94 \\
\hline & Employee & 4.54 & 15.12 \\
\hline & Worker & 38.23 & 40.36 \\
\hline & Missing & 20.02 & 3.28 \\
\hline
\end{tabular}


Table 6: Joint tests results for selection equation and overall statistics

\begin{tabular}{|c|c|c|c|c|}
\hline \multirow[b]{2}{*}{ Null hypothesis } & \multicolumn{2}{|c|}{ Germany } & \multicolumn{2}{|c|}{ France } \\
\hline & $\chi^{2}$ & $\mathbf{p}>\chi^{2}$ & $\chi^{2}$ & $\mathbf{p}>\chi^{2}$ \\
\hline \multicolumn{5}{|l|}{ Tests on gender interactions (mean effects) } \\
\hline Female ${ }^{*}$ Education $=0$ & 103.24 & $(0.00)$ & $1,073.05$ & $(0.00)$ \\
\hline Female $^{*}$ Age $=0$ & 23.35 & $(0.00)$ & 749.56 & $(0.00)$ \\
\hline Female ${ }^{*}$ Number and age children $=0$ & 115.63 & $(0.00)$ & $1,466.13$ & $(0.00)$ \\
\hline Female ${ }^{*}$ Partner's education $=0$ & 1.56 & $(0.67)$ & 44.76 & $(0.00)$ \\
\hline Female $^{*}$ City size $=0$ & 22.89 & $(0.00)$ & 39.57 & $(0.00)$ \\
\hline Female $*$ Quarter $=0$ & 3.37 & $(0.18)$ & & \\
\hline Female $^{*}$ Year $=0$ & 7.69 & $(0.57)$ & 30.51 & $(0.00)$ \\
\hline \multicolumn{5}{|l|}{ Tests on specific coefficients (mean effects) } \\
\hline Education $=0$ & 83.50 & $(0.00)$ & 229.26 & $(0.00)$ \\
\hline Age $=0$ & 63.68 & $(0.00)$ & $1,813.71$ & $(0.00)$ \\
\hline Number and age children $=0$ & 19.48 & $(0.02)$ & 99.14 & $(0.00)$ \\
\hline Partner's education $=0$ & 16.46 & $(0.00)$ & 253.11 & $(0.00)$ \\
\hline City size $=0$ & 21.76 & $(0.00)$ & $1,020.24$ & $(0.00)$ \\
\hline Quarter $=0$ & 78.25 & $(0.00)$ & & \\
\hline Year $=0$ & 106.19 & $(0.00)$ & 85.35 & $(0.00)$ \\
\hline \multicolumn{5}{|l|}{ Tests on scedastic term (dispersion effects) } \\
\hline Homoscedasticity: all coefficients $=0$ & 265.71 & $(0.00)$ & $1,162.98$ & $(0.00)$ \\
\hline Female $*$ Education $=0$ & 79.24 & $(0.00)$ & 167.99 & $(0.00)$ \\
\hline Education $=0$ & 107.77 & $(0.00)$ & 367.09 & $(0.00)$ \\
\hline \multicolumn{5}{|l|}{ Validity of exclusion restrictions } \\
\hline$R^{2}$ test & 0.47 & & 0.39 & \\
\hline Overall Wald test & $15,452.40$ & $(0.00)$ & $2.2 \mathrm{e}+05$ & $(0.00)$ \\
\hline Wald test selection equation & 347.31 & $(0.00)$ & $11,283.92$ & $(0.00)$ \\
\hline Observations & 38,756 & & 654,686 & \\
\hline Numer of individuals & 8,041 & & 330,283 & \\
\hline Log-likelihood & $-27,463.72$ & & $-540,776.61$ & \\
\hline
\end{tabular}


Table 7: Joint tests results for earnings equation

\begin{tabular}{|c|c|c|c|c|}
\hline \multirow[b]{2}{*}{ Null hypothesis } & \multicolumn{2}{|c|}{ Germany } & \multicolumn{2}{|c|}{ France } \\
\hline & $\chi^{2}$ & $\mathbf{p}>\chi^{2}$ & $\chi^{2}$ & $\mathbf{p}>\chi^{2}$ \\
\hline \multicolumn{5}{|c|}{ Tests on gender interactions (mean effects) } \\
\hline Female $*$ Education $=0$ & 90.06 & $(0.00)$ & 305.01 & $(0.00)$ \\
\hline Female $*$ Age $=0$ & 11.96 & $(0.00)$ & $1,321.29$ & $(0.00)$ \\
\hline Female $*$ Tenure $=0$ & 7.64 & $(0.00)$ & $1,544.39$ & $(0.00)$ \\
\hline Female $*$ Firm size $=0$ & 32.03 & $(0.00)$ & 837.62 & $(0.00)$ \\
\hline Female $^{*}$ Industry $=0$ & 131.20 & $(0.00)$ & 413.46 & $(0.00)$ \\
\hline Female ${ }^{*}$ Father's occupation $=0$ & 22.05 & $(0.00)$ & 82.42 & $(0.00)$ \\
\hline Female $^{*}$ Quarter $=0$ & 1.44 & $(0.49)$ & 2.13 & $(0.16)$ \\
\hline Female $*$ Year $=0$ & 8.12 & $(0.52)$ & 52.35 & $(0.00)$ \\
\hline \multicolumn{5}{|c|}{ Tests on specific coefficients (mean effects) } \\
\hline Education $=0$ & $1,812.73$ & $(0.00)$ & $31,158.54$ & $(0.00)$ \\
\hline Age $=0$ & 360.67 & $(0.00)$ & $8,221.81$ & $(0.00)$ \\
\hline Tenure $=0$ & 310.72 & $(0.00)$ & $6,177.22$ & $(0.00)$ \\
\hline Firm size $=0$ & 896.33 & $(0.00)$ & $1,985.40$ & $(0.00)$ \\
\hline Industry $=0$ & 446.89 & $(0.00)$ & $2,262.03$ & $(0.00)$ \\
\hline Father's occupation $=0$ & 264.22 & $(0.00)$ & $1,796.23$ & $(0.00)$ \\
\hline Quarter $=0$ & 135.59 & $(0.00)$ & & \\
\hline Year $=0$ & 397.71 & $(0.00)$ & 884.75 & $(0.00)$ \\
\hline \multicolumn{5}{|c|}{ Tests on scedastic term (dispersion effects) } \\
\hline Homoscedasticity: all coefficients $=0$ & 792.76 & $(0.00)$ & $7,073.68$ & $(0.00)$ \\
\hline Female $*$ Education $=0$ & 205.79 & $(0.00)$ & 584.76 & $(0.00)$ \\
\hline Education $=0$ & 353.20 & $(0.00)$ & $3,450.18$ & $(0.00)$ \\
\hline Wald test earnings equation & $13,410.06$ & $(0.00)$ & $1.8 \mathrm{e}+05$ & $(0.00)$ \\
\hline Non-censored observations & 23,661 & & 404,976 & \\
\hline Number of individuals & 4,928 & & 219,420 & \\
\hline
\end{tabular}


Table 8: Average earnings premium for education (ref.: Level 10 or 11)

\begin{tabular}{|c|c|c|c|c|c|}
\hline \multirow{2}{*}{\multicolumn{2}{|c|}{ Selectivity correction: }} & \multicolumn{2}{|c|}{ Germany } & \multicolumn{2}{|c|}{ France } \\
\hline & & With & Without & With & Without \\
\hline \multirow[t]{9}{*}{ Men } & Level 12 & $0.13(0.03)$ & $0.10(0.02)$ & $0.18(0.00)$ & $0.19(0.00)$ \\
\hline & Level 20 & $0.05(0.01)$ & $0.07(0.01)$ & $0.09(0.00)$ & $0.10(0.00)$ \\
\hline & Level 21 & $0.21(0.01)$ & $0.22(0.01)$ & $0.17(0.00)$ & $0.18(0.00)$ \\
\hline & Level 30 & $0.12(0.01)$ & $0.19(0.01)$ & $0.28(0.01)$ & $0.29(0.01)$ \\
\hline & Level 31 & $0.17(0.02)$ & $0.18(0.02)$ & $0.27(0.00)$ & $0.29(0.00)$ \\
\hline & Level 32 & $0.06(0.08)$ & $0.11(0.05)$ & $0.32(0.01)$ & $0.34(0.00)$ \\
\hline & Level 33 & $0.13(0.02)$ & $0.17(0.01)$ & $0.29(0.01)$ & $0.31(0.01)$ \\
\hline & Level 40 & $0.43(0.02)$ & $0.47(0.01)$ & $0.41(0.00)$ & $0.43(0.00)$ \\
\hline & Level 41 & $0.51(0.02)$ & $0.54(0.01)$ & $0.70(0.00)$ & $0.69(0.00)$ \\
\hline \multirow[t]{9}{*}{ Women } & Level 12 & $0.19(0.02)$ & $0.23(0.02)$ & $0.16(0.00)$ & $0.17(0.00)$ \\
\hline & Level 20 & $0.17(0.02)$ & $0.19(0.01)$ & $0.11(0.00)$ & $0.12(0.00)$ \\
\hline & Level 21 & $0.29(0.02)$ & $0.31(0.01)$ & $0.18(0.00)$ & $0.20(0.00)$ \\
\hline & Level 30 & $0.27(0.02)$ & $0.30(0.02)$ & $0.28(0.01)$ & $0.31(0.01)$ \\
\hline & Level 31 & $0.24(0.02)$ & $0.27(0.02)$ & $0.27(0.00)$ & $0.30(0.00)$ \\
\hline & Level 32 & $0.37(0.05)$ & $0.37(0.05)$ & $0.33(0.00)$ & $0.36(0.00)$ \\
\hline & Level 33 & $0.36(0.02)$ & $0.39(0.02)$ & $0.30(0.01)$ & $0.33(0.01)$ \\
\hline & Level 40 & $0.46(0.02)$ & $0.50(0.02)$ & $0.48(0.00)$ & $0.52(0.00)$ \\
\hline & Level 41 & $0.59(0.02)$ & $0.63(0.02)$ & $0.73(0.01)$ & $0.76(0.00)$ \\
\hline \multirow[t]{9}{*}{ All } & Level 12 & $0.16(0.02)$ & $0.16(0.02)$ & $0.17(0.00)$ & $0.18(0.002)$ \\
\hline & Level 20 & $0.11(0.01)$ & $0.13(0.01)$ & $0.10(0.00)$ & $0.11(0.001)$ \\
\hline & Level 21 & $0.24(0.01)$ & $0.26(0.01)$ & $0.17(0.00)$ & $0.19(0.001)$ \\
\hline & Level 30 & $0.21(0.01)$ & $0.24(0.01)$ & $0.28(0.00)$ & $0.30(0.004)$ \\
\hline & Level 31 & $0.20(0.01)$ & $0.22(0.01)$ & $0.27(0.00)$ & $0.29(0.002)$ \\
\hline & Level 32 & $0.20(0.05)$ & $0.23(0.04)$ & $0.33(0.00)$ & $0.35(0.002)$ \\
\hline & Level 33 & $0.23(0.01)$ & $0.27(0.01)$ & $0.30(0.01)$ & $0.32(0.005)$ \\
\hline & Level 40 & $0.45(0.01)$ & $0.48(0.01)$ & $0.44(0.00)$ & $0.47(0.002)$ \\
\hline & Level 41 & $0.55(0.01)$ & $0.58(0.01)$ & $0.72(0.00)$ & $0.73(0.002)$ \\
\hline
\end{tabular}


Table 9: Dispersion effect of education on earnings (ref.: Level 10 or 11)

\begin{tabular}{lcrrrr}
\hline \hline & & \multicolumn{2}{c}{ Germany } & \multicolumn{2}{c}{ France } \\
Selectivity correction: & With & Without & With & Without \\
\hline \multirow{2}{*}{ Men } & Level 12 & $0.13(0.06)$ & $0.18(0.12)$ & $0.09(0.01)$ & $0.13(0.01)$ \\
& Level 20 & $-0.15(0.06)$ & $-0.18(0.10)$ & $-0.07(0.01)$ & $-0.06(0.01)$ \\
& Level 21 & $-0.10(0.04)$ & $-0.14(0.06)$ & $-0.05(0.01)$ & $-0.02(0.01)$ \\
& Level 30 & $-0.02(0.07)$ & $0.06(0.06)$ & $0.07(0.03)$ & $0.11(0.02)$ \\
& Level 31 & $0.32(0.08)$ & $0.36(0.07)$ & $0.01(0.02)$ & $0.05(0.02)$ \\
& Level 32 & $0.53(0.16)$ & $0.59(0.15)$ & $0.34(0.02)$ & $0.39(0.02)$ \\
& Level 33 & $0.17(0.09)$ & $0.20(0.08)$ & $0.11(0.04)$ & $0.17(0.04)$ \\
& Level 40 & $0.30(0.08)$ & $0.39(0.07)$ & $0.08(0.01)$ & $0.14(0.01)$ \\
& Level 41 & $0.63(0.07)$ & $0.75(0.06)$ & $0.60(0.01)$ & $0.64(0.01)$ \\
\hline \multirow{2}{*}{ Women } & Level 12 & $-0.33(0.07)$ & $-0.39(0.07)$ & $0.01(0.01)$ & $0.01(0.01)$ \\
& Level 20 & $-0.55(0.05)$ & $-0.55(0.05)$ & $-0.14(0.01)$ & $-0.14(0.01)$ \\
& Level 21 & $-0.53(0.05)$ & $-0.55(0.05)$ & $-0.25(0.01)$ & $-0.25(0.01)$ \\
& Level 30 & $-0.65(0.06)$ & $-0.64(0.06)$ & $-0.33(0.03)$ & $-0.33(0.03)$ \\
Level 31 & $-0.61(0.08)$ & $-0.60(0.08)$ & $-0.26(0.02)$ & $-0.25(0.02)$ \\
& Level 32 & $-0.20(0.09)$ & $0.21(0.13)$ & $0.01(0.01)$ & $0.02(0.01)$ \\
& Level 33 & $-0.20(0.07)$ & $-0.21(0.07)$ & $-0.20(0.03)$ & $-0.19(0.03)$ \\
& Level 40 & $-0.14(0.08)$ & $-0.13(0.08)$ & $-0.22(0.01)$ & $-0.21(0.01)$ \\
& Level 41 & $-0.09(0.06)$ & $-0.08(0.06)$ & $0.42(0.01)$ & $0.44(0.01)$ \\
\hline \multirow{6}{*}{ All } & Level 12 & $-0.08(0.06)$ & $-0.12(0.07)$ & $0.05(0.01)$ & $0.07(0.01)$ \\
& Level 20 & $-0.33(0.04)$ & $-0.30(0.04)$ & $-0.10(0.01)$ & $-0.10(0.01)$ \\
Level 21 & $-0.30(0.04)$ & $-0.28(0.04)$ & $-0.15(0.01)$ & $-0.13(0.01)$ \\
& Level 30 & $-0.31(0.05)$ & $-0.26(0.04)$ & $-0.13(0.02)$ & $-0.10(0.02)$ \\
Level 31 & $-0.10(0.06)$ & $-0.08(0.05)$ & $-0.12(0.01)$ & $-0.10(0.01)$ \\
& Level 32 & $0.20(0.09)$ & $0.19(0.10)$ & $0.18(0.01)$ & $0.21(0.01)$ \\
Level 33 & $0.00(0.07)$ & $0.03(0.05)$ & $-0.04(0.03)$ & $-0.01(0.02)$ \\
& Level 40 & $0.10(0.05)$ & $0.16(0.05)$ & $-0.07(0.01)$ & $-0.03(0.01)$ \\
Level 41 & $0.30(0.05)$ & $0.37(0.04)$ & $0.51(0.01)$ & $0.54(0.01)$ \\
\hline \hline
\end{tabular}

